\title{
タッピング運動を利用した咬合採得法に関する研究
}

九州歯科大学大学院菌学研究科菌科補緅学第 1 専攻（指導：豊田静夫教授）

和久田一成

昭和59年 8 月 21 日受付

本論文の要旨は, 昭和58年 2 月 19 日, 日本補緅菌科学会九州支部会, 昭和 58 年 5 月 28 日, 第43回九州歯科 学会総会において発表した。

\section{Study on Maxillomandibular Registration with Use of Tapping Movement Kazushige Wakuda}

First Department of Prosthetic Dentistry (Director : Prof. Shizuo Toyoda) Kyushu Dental College, Kitakyushu, Japan

In making a complete denture, maxillomandibular registration is very important step and various methods for registration have been reported. Of these methods, tapping movement has often been used clinically. Therefore, effectiveness of use of tapping movement was examined.

For this study, tapping movement with the vertical dimension changed was recorded for 20 dentulous subjects and 13 denture-wearing subjects. Sweep recording of 50 tapping movements without overlapping was made possible by connecting a 2 pen recorder to a Mandibular Kinesiograph. On the basis of the recordings, anteroposterior displacement and lateral displacement of tapping point, tapping area, variance in tapping point, at various mandibular positions, were obtained.

The results were as follows:

1. The maximum anteroposterior displacement of tapping at the centric occlusion in 20 dentulous subjects was $0.05 \pm 0.12 \mathrm{~mm}$ anterior and $0.29 \pm 0.13 \mathrm{~mm}$ posterior with an average of $0.09 \pm 0.10 \mathrm{~mm}$ posterior. The maximum displacement was $0.13 \pm 0.06 \mathrm{~mm}$ on the right and $0.21 \pm 0.10 \mathrm{~mm}$ on the left with an average of $0.01 \pm 0.07 \mathrm{~mm}$ on the right. The maximum tapping area was $0.06 \mathrm{~mm}^{2}$ and the minimum was $0.00 \mathrm{~mm}^{2}$ with an average of $0.02 \pm 0.02 \mathrm{~mm}^{2}$.

2. The anteroposterior displacement of the tapping point at various mandibular positions in the dentulous subjects increased as the vertical dimension was raised. However, the lateral displacement did not show any significant difference.

3. The tapping area in the dentulous subjects increased as the vertical dimension was raised.

4. In variance of tapping point at different mandibular positions in dentulous subjects, anteroposterior variance was significantly greater in $64.2 \%$ on the average and lateral variance in $12.9 \%$. 
5. The anteroposterior displacement and lateral displacement at various mandibular positions with the vertical dimension lowered in the denture-wearing subjects did not show any significant difference when compared with the displacement $(0.46 \pm 0.29 \mathrm{~mm}$ anterior and $0.16 \pm 0.30 \mathrm{~mm}$ on the right to the centric relation) at the appropriate vertical dimension. The lateral displacement did not show significant difference even when the vertical dimension was raised. However, the anteroposterior displacement increased as the vertical dimension was increased and the displacement was $1.09 \pm 0.74$ $\mathrm{mm}$ anterior to the centric relation at the mandibular position raised by $6 \mathrm{~mm}$.

6. The tapping area at various mandibular positions with the vertical dimension lowered in the denture-wearing subjects did not show any significant differnce in comparison with the tapping area $\left(0.06 \pm 0.08 \mathrm{~mm}^{2}\right)$ with the appropriate vertical dimension. However, as the vertical dimension was raised, the tapping area increased and the area was $0.39 \pm 0.46 \mathrm{~mm}^{2}$ at the mandibular position raised by $6 \mathrm{~mm}$.

7. When the anteroposterior variance was compared with the lateral variance of the tapping point at various mandibular positions in the denture-wearing subjects, the anteroposterior variance was significantly greater in $46.1 \%$ on the average and the lateral variance was significantly greater in $13.5 \%$ on the average.

Key words : Maxillomandibular registration/Tapping movement/Tapping point/ Tapping area

\section{緒言}

総義歯を作製する際，適切な上下顎の水平的対位関係 を決定することは，非常に重要なステップである。とこ ろが，その方法として，ゴシックアーチ描記法1'，タッ ピング運動を行わせる方法2-41，ワルクホッフ小球法, 壦下運動を利用する方法 ${ }^{5}, 6$, 筋触診法, 筋電図を利用 する方法7)，マイオモ二タ一を利用する方法 $\left.{ }^{8},{ }^{9}\right)$ など， 従来から多くの方法が報告されているが，いまだに確定 的なものは無く, 臨床では, それらのうちの1つを利用 するか，あるいは，いくつかを組み合わせて判定してい るのが現状である。

これらの方法のうちで，タッピング運動を利用する方 法は, 特別な器具を必要とせず, 患者自身の生理的機能 を利用することにより，有曾顎当時の中心咬合位に近接 した位置での峧合記録が得られるとされており く臨床に用いられる方法であるが，乙の方法を用いる場 合には，咬合高径が正しく決定されていることを前提と している111。しかし，臨床においては，艾合高径を変 化させた場合にも, 水平的対位関係の決定確認方法とし て用いることがあり，その際，乙の方法が有効であるか 否かの報告は少ない。
また，丸山 $(1973)^{121}$ ，名波 $(1978)^{13)}$ は, タッピン グ運動の咬合高径確認法としての可能性を示唆している が，河江 $\left.(1980)^{14}\right)$ は, タッピング運動を咬合高径決定 の手段として利用するととに否定的な見解を述べてい る。

そこで著者は，咬合採得時にタッピング運動を利用す

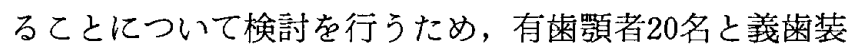
着者13名を被験者として，咬合高径を種々に変化させた 時の，タッピングポイントのばらつきを記録分析した。 その結果，興味ある知見を得たので報告する。

\section{実 酫 方 法}

\section{1. 予備実験}

本研究は，咬合高径を変化させるとタッピングポイン トの偏位量, タッピングエリア, タッピングポイントの ばらつきがどの程度変化するかを調べるととを目的とし ている。したがって，咬合高径を変化させ，その位置で タッピング運動をさせる装置として, 口内ゴシックアー チトレーサを利用した咬合高径保持装置を用いた（図 1 ).

またタッピング運動の測定装置として， Myo- 


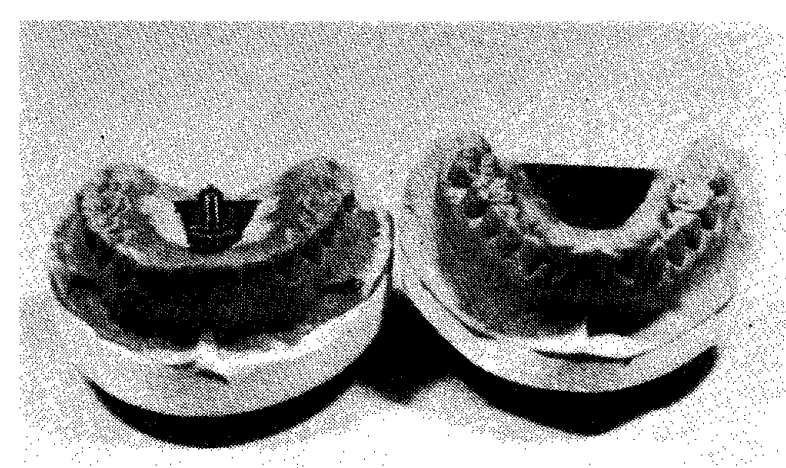

図 1 有雨顎者用咬合高径保持装置

Tronics 社製 Mandibular Kinesiograph K 5 型（以 下 M.K.G. と略す) を用いた。 M.K.G.は，下顎運 動の三次元測定装置であり，下顎中切歯画頸部に取り付 けた永久磁石の移動沾り生ずる磁場の変化を，一定の 空間的位置関係に設定したセンサがとらえ，ブラウン管 上に，下須運動として描記するものである。しかし， M.K.G. を単独で用いた記録では，タッピング運動の 䖝跡が重なり合ってしまい，各々の運動を明確にとらえ ることはできない，そこで，各タッピング 運動を重な ることなくとらえるために，本研究では，M.K.G. に 理化電気社製 2 pen recorder $\mathrm{R} 202$ (以下 2 pen recorder と略す) を接続して, タッピング運動を掃引 記録した（図 2)。乙の記録をもとに，各多ッピングポ イントの前後的偏位量, 左右的偏位量を Kontron 社製 画像解析装置 M.O.P. 20 (以下 M.O.P. 20 と格す, 図 3) で計測した。

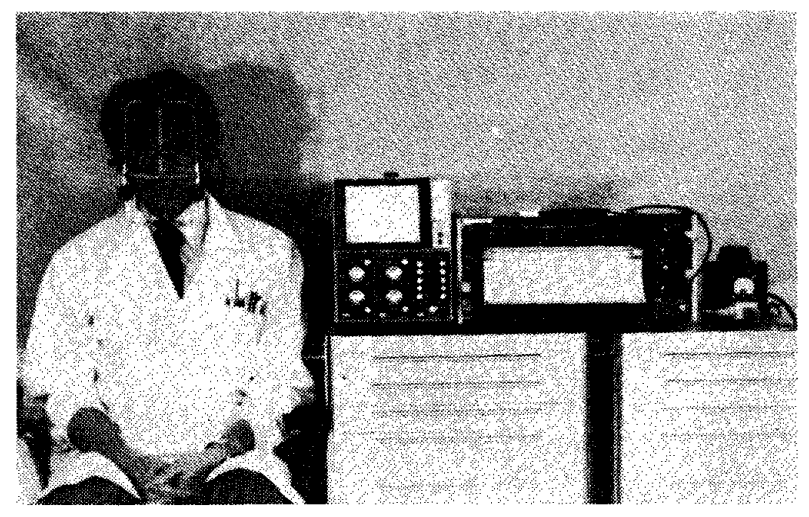

図 2 タッピング運動の測定に用いた装置

ところが，本実験では，M.K. G. 自体の精度， M.O.P. 20 使用時の測定誤差, タッピングストローク 規定の有無による影響，咬合高径保持装置装着の影響， 咬合高径挙上時のスタイラス傾斜の影㗽などの問題が考

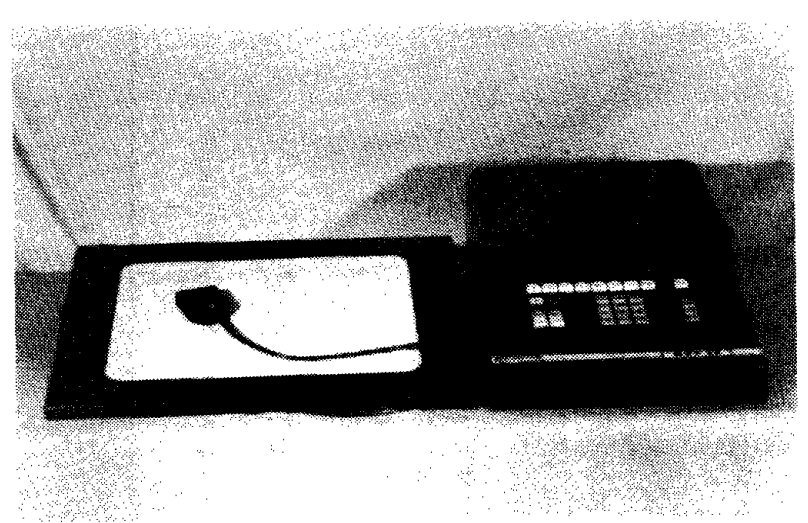

図 3 画像解析装置 MOP-20

えられるため，それらの項目について，あらかじめ検討 を行った。

\section{A. M.K.G. の精度}

1. 分解能

X-Y recorder 上七で, 明碓に 2 測定点として認めるこ とができる最小の磁石移動距離を，M.K.G. の分解能 とした。微動装置は, 副尺によって,1/100 mmまで読み 取ることができる成茂科学器械社製電気生理用マイクロ マニュピレータを使用し, 磁石は, 長さ $40 \mathrm{~cm}$ のアクリ ル棒を介して微動装置の可動部に固定した（戍4）。ま

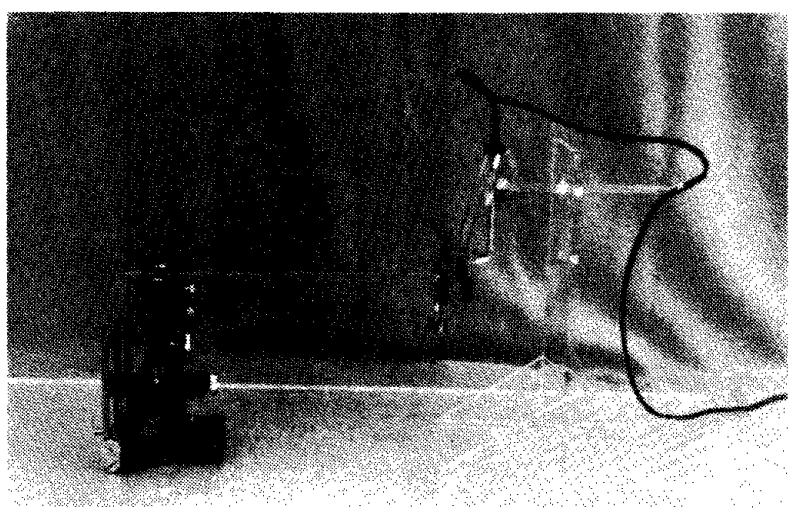

図 4 M.K.G. の精度試験に用いたマイクロマニ ュピレータ

た，センサアレイの固定には，アクリル板を応用した固 定装置を用い，センサアレイの中央縦軸が沐面と开直で あること, 磁石が原点に位置していること, 微動装置に よる磁石の移動が，各センサに対して，垂直および平行 になっていることを確認した。これらの実験装置は，磁 性体から可及的に離した状態とし，磁石の動きを M.K. G. と接続した渡辺測器社製 X-Y recorder WX 4403 型上で記録した，その結果，分解能は $0.04 \mathrm{~mm}$ である ことがわかった。 


\section{2. 描記特性}

M.K.G. の水平面における描記特性を知るために， 磁石を $1 \mathrm{~mm}$ ずつの闑隔で, 原点を中心として, 前後 方向に $4 \mathrm{~mm}$, 左右方向に $5 \mathrm{~mm}$ まで移動させ, $\mathrm{X}-\mathrm{Y}$ recorder 上に99点を記録した。 その值をもとに，

誤差 $=\frac{\mid \text { 夎標值一実動值 } \mid}{\text { 実動值 }} \times 100(\%)$

という式で誤差を算出した。その結果，最大誤差は，磁 石の $2 \mathrm{~mm}$ 移動時で前後方向では $5.0 \%$ ，左右方向では $2.8 \%$ であり， $4 \mathrm{~mm}$ 移動時で前後方向では $6.0 \%$, 左右 方向では3.4\%であった。

以上のととから，タッピング運動を水平面でとらえる 場合，その範用が原点より $4.25 \mathrm{~mm}$ までであるため ${ }^{15) ，}$ M.K.G. は本研究の目的に対して十分な精度を有して いることがわかった。

\section{B. M.O.P. 200測定悞差}

本研究では, 2 pen recorder により記録したタッピ ングポイントの偏位量を，M.O.P. 20を用いて計測し た。本装置を使用するととにより，中心位に相当する基 準点とタッピングポイントの偏位点との 2 点をカーソル でさす操作を行うだけで，その 2 点間の距離を求めるこ とができる。そこで，乙の装置を用いてタッピングポイ ントの偏位量を測定する場合の䛊差について検討した。

雨宮ら $(1970)^{15)}$ は中心位を基準として，タッピングボ イントが 0.5〜 4.25mm の範囲内に存在したと述べてい る.そこで M.O.P. 20に M.K.G.と2 pen recorder の倍率をインプットした後， $0.5 \mathrm{~mm}$ と $4.0 \mathrm{~mm}$ に相当 する 2 点間を測定したところ, 表 1 に示すような結果を

表 1 画像解析装置の測定䛊差

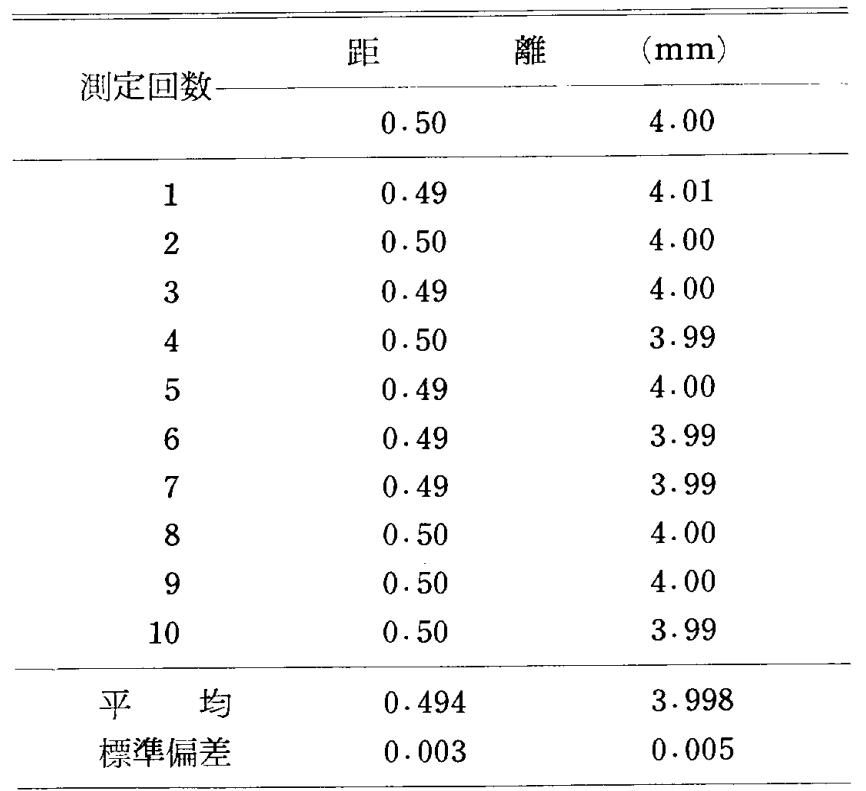

得た。すなわち，M.O.P. 20 は，本研究に十分な精度 を有していることがわかった。

\section{C．タッピングストローク規定の影響}

タッピング運動を行わせる場合, 生理的運動を重要視 して，被験者固有のタッピングストロークで行わせる場 合と,メトロノ一ムなどを利用して行わせる場合とがあ る.そこで，タッピングストロータを規定しない場合 と, 規定した場合とで, タッピングポイントの偏位量, タッピングエリアに有意差があるかどうかを検討した。

通法に従って M.K.G. を装着した10名の有歯敄被験 者で，咬合高径を挙上せず，被験者固有のタッピングス トロークで運動させたもの，メトロノームで 1 秒間に 1 回，2回，3 回とタッピングストロークを規定して運動 させたものの 4 種について，タッピングポイントの前後 的编位量, 左右的偏位量, タッピングエリアの 3 項目を 比較検討した。 その際, 前後的偏位量, 左右的偏位量 は，50回のタッピング運動の平均值とし，タッピングエ リアについては, 前後的偏位量と左在的偏位量の恮準惼 差をもとに算出した。罒 5 は，その概略を示したもので ある.図中の各点は, 2 pen recorder で記録したタッ ピング運動の前後成分, 左左成分を合成して得られたタ ッピングポイントであり，Mは，乙れらの平均的位置で

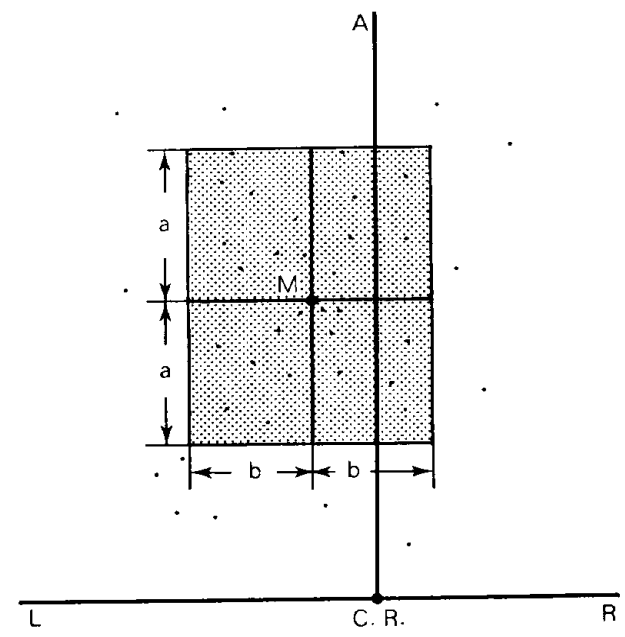

図 5 タッピングエリアの模式図

目：タッピングエリア $\left(2 \mathrm{a} \times 2 \mathrm{~b} \mathrm{~mm}^{2}\right)$

$\mathrm{a}$ ：タッピングポイントの前後的偏位量の 1 S.D.

b : タッピングポイントの左右的偏位量の 1 S.D.

$\mathbf{M}$ ：タッピングポイントの平均的位置

C.R. : 中心位

A : 前方

$\mathrm{R}$ ：右側

$\mathrm{L} ：$ 左側 
ある．前後成分のばらつきの指標である標準偏差 $\mathbf{a}$ と左 在成分のばらつきの指標である標準偏差 $\mathrm{b} と を も と に ，$ 本研究では, $2 \mathrm{a} \times 2 \mathrm{~b}$ をッピングエリアとして算出し た。その結果が，表 2 である。

各データ間で, 対応のある 2 組の平均值の差の検定を 行ったところ, 前後的偏位量, 左右的偏位量, タッピン グェリアの 3 項目全てについて，有意差は認められなか った。そこで，本研究では，タッピングストロークを規 定せず被験者固有のタッピングストロータで運動させる ことにした。

表 2 タッピングストローク規定の影響

\begin{tabular}{|c|c|c|c|c|}
\hline \multirow{2}{*}{ 被験者 } & \multicolumn{4}{|c|}{ タッピングストローク } \\
\hline & 固有 & $1 / \mathrm{S}$ & $2 / \mathrm{S}$ & $3 / \mathrm{S}$ \\
\hline 1 & $\begin{array}{l}1.22 \\
0.00 \\
0.05\end{array}$ & $\begin{array}{r}1.11 \\
-0.40 \\
0.06\end{array}$ & $\begin{array}{r}0.79 \\
-0.37 \\
0.04\end{array}$ & $\begin{array}{r}0.53 \\
-0.42 \\
0.05\end{array}$ \\
\hline 2 & $\begin{array}{r}0.10 \\
+0.11 \\
0.03\end{array}$ & $\begin{array}{r}0.34 \\
+0.02 \\
0.03\end{array}$ & $\begin{array}{r}0.41 \\
-0.17 \\
0.04\end{array}$ & $\begin{array}{r}0.26 \\
-0.13 \\
0.03\end{array}$ \\
\hline 3 & $\begin{array}{r}0.41 \\
-0.29 \\
0.02\end{array}$ & $\begin{array}{r}0.68 \\
-0.64 \\
0.04\end{array}$ & $\begin{array}{r}0.47 \\
-0.53 \\
0.03\end{array}$ & $\begin{array}{r}0.33 \\
-0.49 \\
0.03\end{array}$ \\
\hline 4 & $\begin{array}{r}0.39 \\
+0.24 \\
0.01\end{array}$ & $\begin{array}{r}0.59 \\
+0.04 \\
0.02\end{array}$ & $\begin{array}{r}0.38 \\
+0.02 \\
0.02\end{array}$ & $\begin{array}{r}0.30 \\
-0.05 \\
0.01\end{array}$ \\
\hline 5 & $\begin{array}{r}0.73 \\
-0.45 \\
0.01\end{array}$ & $\begin{array}{r}0.65 \\
-0.34 \\
0.03\end{array}$ & $\begin{array}{r}0.58 \\
-0.29 \\
0.01\end{array}$ & $\begin{array}{r}0.68 \\
-0.19 \\
0.04\end{array}$ \\
\hline 6 & $\begin{array}{r}0.20 \\
-0.08 \\
0.01\end{array}$ & $\begin{array}{r}0.18 \\
-0.18 \\
0.02\end{array}$ & $\begin{array}{r}0.24 \\
-0.15 \\
0.01\end{array}$ & $\begin{array}{r}0.25 \\
-0.14 \\
0.02\end{array}$ \\
\hline 7 & $\begin{array}{r}0.52 \\
+0.04 \\
0.01\end{array}$ & $\begin{array}{r}0.43 \\
+0.07 \\
0.02\end{array}$ & $\begin{array}{r}0.40 \\
+0.06 \\
0.01\end{array}$ & $\begin{array}{r}0.38 \\
+0.06 \\
0.01\end{array}$ \\
\hline 8 & $\begin{array}{r}1.04 \\
+0.07 \\
0.00\end{array}$ & $\begin{array}{r}0.85 \\
+0.05 \\
0.00\end{array}$ & $\begin{array}{r}0.87 \\
+0.04 \\
0.00\end{array}$ & $\begin{array}{r}0.87 \\
+0.03 \\
0.00\end{array}$ \\
\hline 9 & $\begin{array}{r}0.29 \\
+0.03 \\
0.00\end{array}$ & $\begin{array}{r}0.71 \\
+0.08 \\
0.01\end{array}$ & $\begin{array}{r}0.63 \\
+0.05 \\
0.01\end{array}$ & $\begin{array}{r}0.57 \\
+0.05 \\
0.00\end{array}$ \\
\hline 10 & $\begin{array}{r}0.27 \\
-0.31 \\
0.02\end{array}$ & $\begin{array}{r}0.36 \\
-0.38 \\
0.02\end{array}$ & $\begin{array}{r}0.41 \\
-0.07 \\
0.02\end{array}$ & $\begin{array}{r}0.42 \\
+0.01 \\
0.02\end{array}$ \\
\hline 平均 & $\begin{array}{r}0.52 \\
-0.06 \\
0.02\end{array}$ & $\begin{array}{r}0.59 \\
-0.17 \\
0.03\end{array}$ & $\begin{array}{r}0.52 \\
-0.14 \\
0.02\end{array}$ & $\begin{array}{r}0.46 \\
-0.13 \\
0.02\end{array}$ \\
\hline
\end{tabular}

上段：前後的偏位量 単位：mm 中段: 左右的偏位量 単位: $\mathrm{mm}$

$$
\begin{aligned}
& + \text { : 右側 } \\
& - \text { ：左側 }
\end{aligned}
$$

下段：タッヒングエリア 単位： $\mathrm{mm}^{2}$

\section{D．咬合高径保持装置装着の影響}

咬合高径を変化させ，その位置でタッピング運動をさ せる装置として，口内ゴシックアーチトレーサを用いた 咬合高径保持装置を作製した（図 1 参照)。乙の装置を 口腔内に装着した場合，多少舌房を侵害する恐れもあ り，そのため，タッピング運動に何らかの影響を及ぼす ことも予想される。そこで，咬合高径保持装置がタッピ ング運動に及ぼす影響を調べるために，10名の有雨顎被 験者で咬合高径を挙上せず，咬合高径保持装置を装着し ていない場合と装着した場合とについて，タッピングポ

\section{表 3 咬合高佳保持装置装着の影響}

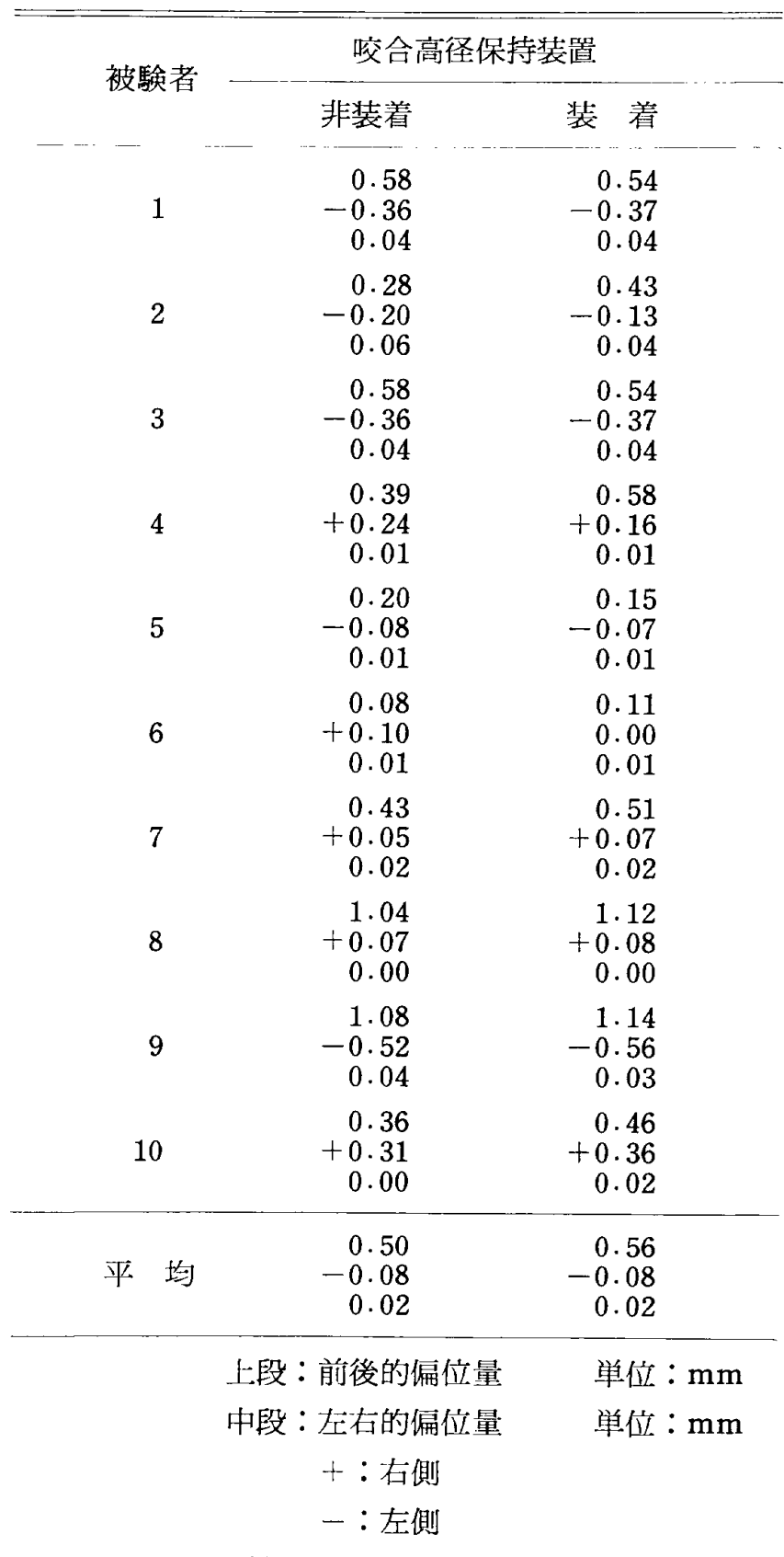

下段：タッピングエリア 単位 $: \mathrm{mm}^{2}$ 
イントの前後的偏位量, 左有的偏位量, タッピングエリ アを求めた。その結果が表 3 である.

各デー夕閒で，対応のある 2 組の平均值の差の検定を 行ったところ, 前後的偏位量, 左石的偏位量, タッピン グエリアの 3 項目全てについて, 有意差は認められなか った。つまり，咬合高径保持装置装着がタッピング運動 に及ぼす影響は無視できるものと思われる．

E．咬合高径挙上時のスタイラスの傾斜による影響 咬合高径保持装置は，スタイラスのネジ調整するこ とにより，咬合高径を自由に増減できるようになってい る。しかし，咬合高徍を挙上していない状態で，スタイ ラスがプレートに対して可及的に瑇直となるように設定 してあるため，ネジを調整して咬合高径を挙上するに従 って，スタイラスはプレートに対して，前方䪸斜した状 態となる．そこで，スタイラスの前方傾斜がタッピング 運動に及ぼす影響を調べた。10名の有歯顎被験者につい て，切歯部で咬合高径を垂直的に $10 \mathrm{~mm}$ 举上し，スタ イラスの前方傾斜をそのままにしてタッビング連動を行 わせた場合と，スタイラスがプレートに対して垂直とな るように再調整してタッピング運動を行わせた場合とに ついて, タッピングポイントの前後的偏位量, 左有的偏 位量, タッピングエリアを求めた。その結果が表 4 であ る.

各デー夕間で，対応のある 2 組の平均值の差の検定を 行ったところ, 前後的偏位量, 左右的偏位量, タッピン グェリアの3 項目全てについて，有意差は認められなか った・そこで，スタイラスがブレートに対して直とな るように，各顎位で再調整は行わず，最初に設定した状 態のまま，スタイラスのネジを回転し，咬合高径を増娍 させることにした。

II. 本実験

\section{A . 実験 I}

\section{1. 被験者}

被験者は，いわゆる個性正常咬合を有する23歳から31 歳までの九州㦱科大学琞子学生 20 名とした。なお, 被験 者の選択は，以下の基準に從って行った。

a . 第 3 大曰㯨以外の久損歯あるいは過剩柬のないも の.

b . 上下顎ともに侓全な天然雪列を有するか，歯冠修 復物があっても少数で, 雬列および歯牙の形態と機能 を損っていないもの.

c . 画牙の著しい捻転, 転位, 傾斜のないもの.

d. 開咬, 過蓋咬合, 反対咬合でないもの.

e . 永久泣列か洗成しており，中心咬合位の安定して
表 4 スタイラスの傾斜による影響

\begin{tabular}{|c|c|c|}
\hline \multirow{2}{*}{ 被験者 } & \multicolumn{2}{|c|}{ スタイラスの傾斜 } \\
\hline & 前 傾 & 垂 直 \\
\hline 1 & $\begin{array}{r}0.57 \\
-0.65 \\
0.08\end{array}$ & $\begin{array}{r}0.62 \\
-0.71 \\
0.10\end{array}$ \\
\hline 2 & $\begin{array}{r}1.98 \\
-0.89 \\
1.15\end{array}$ & $\begin{array}{r}2.18 \\
-0.65 \\
1.15\end{array}$ \\
\hline 3 & $\begin{array}{r}1.89 \\
-0.10 \\
0.44\end{array}$ & $\begin{array}{r}1.42 \\
-0.07 \\
0.28\end{array}$ \\
\hline 4 & $\begin{array}{r}2.52 \\
-0.16 \\
1.56\end{array}$ & $\begin{array}{r}2.89 \\
-0.06 \\
1.34\end{array}$ \\
\hline 5 & $\begin{array}{r}0.64 \\
-0.25 \\
0.26\end{array}$ & $\begin{array}{r}0.79 \\
-0.32 \\
0.27\end{array}$ \\
\hline 6 & $\begin{array}{r}3.30 \\
+1.08 \\
0.75\end{array}$ & $\begin{array}{r}2.66 \\
+0.88 \\
0.69\end{array}$ \\
\hline 7 & $\begin{array}{r}1.14 \\
+0.15 \\
0.13\end{array}$ & $\begin{array}{r}1.49 \\
+0.05 \\
0.13\end{array}$ \\
\hline 8 & $\begin{array}{r}0.40 \\
+0.07 \\
0.21\end{array}$ & $\begin{array}{r}0.91 \\
+0.04 \\
0.27\end{array}$ \\
\hline 9 & $\begin{array}{r}5.98 \\
-1.01 \\
2.31\end{array}$ & $\begin{array}{r}3.95 \\
-0.49 \\
2.55\end{array}$ \\
\hline 10 & $\begin{array}{r}1.13 \\
-0.21 \\
0.07\end{array}$ & $\begin{array}{r}0.74 \\
-0.03 \\
0.07\end{array}$ \\
\hline 承均 & $\begin{array}{r}1.96 \\
-0.20 \\
0.70\end{array}$ & $\begin{array}{r}1.77 \\
-0.14 \\
0.69\end{array}$ \\
\hline & $\begin{array}{l}\text { 上段: 前後的偏位量 } \\
\text { 中段: 左右的偏位量 } \\
+ \text { ：右側 } \\
- \text { : 左側 }\end{array}$ & $\begin{array}{l}\text { 単位: } \mathrm{mm} \\
\text { 単位 }: \mathrm{mm}\end{array}$ \\
\hline
\end{tabular}

下段：タッピングエリア 単位： $\mathrm{mm}^{2}$

いるもの.

$\mathrm{f}$. 顎関節, 咀嚼筋群などの顎口腔系に異常が認めら れないもの.

g. 矯正治燎の既往歴のないもの.

\section{2 . 実験準備}

被験者の上下顎幽列を，ビニルシリコン印象材（而至 社製エクザフレックス) で印象採得を行い，超硬石育 (而至社製フジロック) を用いて模型を作製した。その 後, 鼻耳道線を基準として顔可計测を行い，上下顎模型 を咬合器に付着した。 
本研究は，咬合高径を変化させると，タッピンダポイ ントの偏位量, タッピングエリア, タッピングポイント のばらつきがどの程度変化するかを知ることを目的とし ている．そのため，咬合高径を変化させ，その位置で夕 ッピング運動をさせる装置として，口内ゴシックアーチ トレーサを応用した咬合高径保持装置をあらかじめ模型 上で作製した，作製にあたり，装置が舌房をできるだけ 侵害しないようにするため，下䫟にはプレートを，上顎 にはスタイラスを用い, 下頡のプレートは, 咬合平面と 可及的に一致させた。また，スタイラスの位置は，下顎 左右第 1 大臼歯近心舌側咬頭頂を結ぶ線と正中線との交 点とし，咬合高径を挙上していない状態で，スタイラス がプレートに対して重直となるようにした。プレート， スタイラスの天然蒾への固定には，即時重合レジン（而 至社製オストロン) で作製したレシンシーネを用いた (図 1 参照).

模型上で作製した咬合高径保持装置を，あらかじめ被 験者に試適し，適合状態を確誌した。

つぎに，咬合高经挙上量にあわせて，咬合高径保持装 置のスタイラスの長さを咬合器上で調整した。すなわ ち, 中心咬合位を Vertical Dimension \pm 0 (以下 V.D. \pm 0 と略す) とし， $2 \mathrm{~mm}$ ずつ $10 \mathrm{~mm}$ まで咬合高 径を垂直的に挙上し，その頢位をそれぞれ V.D. +2 , V.D. +4 , V.D. +6 , V.D. +8 , V.D. +10 とした.

被験者を曾科用治潦椅子にカンペル平面が沐面と平行 になるように座らせ, 安頭台により頭部を安定させた。

M.K.G., 2 pen recorder を約15分間ウォーミングア ップした後，M.K.G.を通法に従って調整した。な お, 電気的な装置の安定に対して, 最も大きな影響を与 える⿴子として，電源電圧の変動による増幅度の変化が 考えられるため, 電源電圧安定装置を使用し, 電圧の変 動による影響を受けないように考慮した。また，咬合高 径を挙上した場合, 磁石とセンサアレイとの関係が変化 するため, タッピング運動を記録する前に，各買位でセ ンサアレイの位置を再調整した。

3 . 測定項目

本実験では，いわゆる個性正常咬合者を対象として， 咬合高径の変化とそれによるタッピングポイントの前後 的偏位量, 左右的偏位量, タッピングエリア, タッピン グポイントのばらつきについて調べた。

a. 中心盿合位でのタッピングポイントの前後的偏位 量, 左右的偏位量, タッピングエリア

被験者に上下顎歯列が自然に咬合する䫕位をとらせ， その位置を中心咬合位として，2 pen recorder 上に記
録した・つぎに，50回タッピング運動を行わせ，中心咬 合位を基準として,タッピングポイントの前後的偏位量, 左右的偏位量, タッピングエリアを求めた。

b . 咬合高径を変化させた場合のタッピングポイントの 前後的偏位量, 左右的偏位量

V.D. \pm 0 から順に V.D. +10 まで㖫合高径を挙上さ せた場合と，V.D. +10 から順に V.D. \pm 0 まで咬合高 径を減少させた場合とで，各影位で50回タッピング運動 を行わせ, 中心位を基準として, タッピングポイントの 前後的偏位量, 左右的偏位量を求奻た。

c. 咬合高径を変化させた場合のタッピングエリアの変 化

V.D.土0から順に V.D.+10まで咬合高径を挙上さ せた場合と，V.D.+10から順に V.D. 上0まで峧合高 径を減少させた場合とで，各頜位で50回タッピング運動 を行わせ，得られたデータをもとにタッピングエリアを 算出した。

d. 各顎位におけるタッピングポイントの前後的ばらつ きと左右的ばらつき

タッピングポイントのばらつきの程度が, 前後的に大 きいのか，あるいは，左右的に大きいのかを知るため に, 各顎位における前後的偏位と左右的偏位の分散の比 の検定を行った.

\section{B. 実験 II}

\section{1. 被験者}

被験者は, 本学付属病院補経科に義雪作製を希望して 来院した，53歳から76歳までの男性 8 名, 女性 5 名, 計 13名とした。な招, 被験者の選択は, 以下の基準に従っ て行った。

a 、顎関節，頧運動および咀嚼機能に障害を及佂すよ うな, 全身的, 局所的疾患の既往症および現症が無い 屯.

b . 上下顎の顎堤形態, 対位関係および顎粘膜状態が 良好なもの.

c. すれ違い咬合者で, 残存菌どうしの咬合接触が無 く，咬合高径をさげることが可能なもの.

d. 残存柬の動摇が生理的範囲内であり, 咬合高径保 持装置の維持安定が確実であるもの.

e . 現在使用している義柬の咬合高径, 咬合関係供 常が認められないもの.

\section{2. 実験準備}

概形模型上で作製した個人トレーを用い，辺縁形成し た後, チオコールラバー印象材（而至社製シュールフレ ックス）で，上下顎の印象採得を行い，超硬石高（而至 
社製フジロック）を用いて模型を作製した。その模型上 で, 通法行従って, 咬合床を作製した。被験者は, 現在 使用している義䨑の咬合高径に慣れており，臨林的にも 異常症状が譛められない，そこで，現在使用している義 粷の咬合高径を適正咬合高径として咬合採得を行った。 その後, 鼻耳道線を基準として, 顔弓計測を行い, 上下 澦模型を咬合器に付着した。

タッピング運動時の咬合高径保持装置の動摇を最小限 にするため，装置の作製にあたり，クラスプの数は可能 な限り多数とし，クラスプと林とを $\mathrm{Ni}-\mathrm{Cr}$ 合金（三金 社製サニリウム) でワンピース鋳造した。ゴシックアー チトレーサは，金属床部に即時重合レジンで固定した。 ての時，舌房をできるだけ侵害しないように注意し，有 菌顎者同椂，下㖽にプレート，上顎にスタイラスを用い た.下顎のプレートは咬合平面と可及的に平行とし，上 靧のスタイラスの位置は，下顎左右䨑槽頂の近遠心的中 央を結ぶ線と正中線との交点とし，咬合高径を增減して いない状態で，プレートに対して垂直となるようにした (図6).

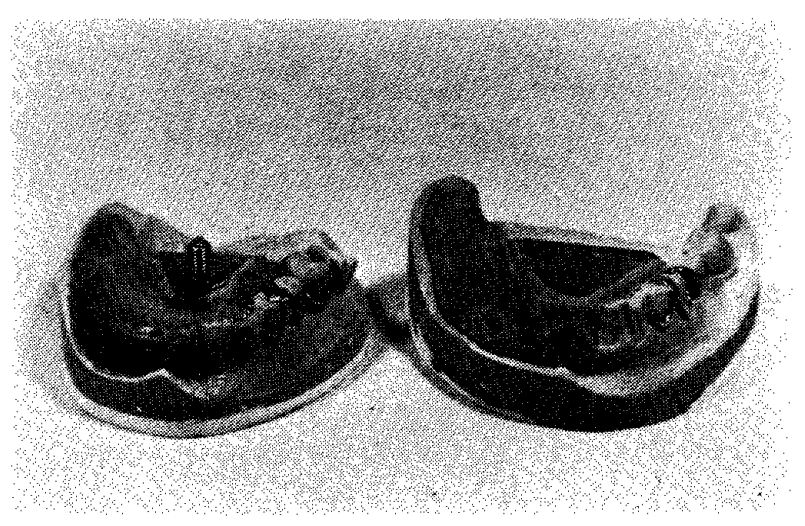

図 6 義囦装着者用咬合高径保持装置

模型上で作製した咬合高径保持装置を，あらかじめ被 験者に試適し, クラスプや床部の適合状態を確誌した。

つぎに，咬合高径の増減量にあわせて，咬合高径保持 装置のスタイラスの長さを咬合器上で調整した。すなお ち, 被験者の現在使用している義歯の咬合高径を基準と して，その咬合高径を Vertical Dimension士0（以下 V.D. \pm 0 と略す) とし, 㕮合高径を垂直的に $1 \mathrm{~mm}$, $2 \mathrm{~mm}, 4 \mathrm{~mm}, 6 \mathrm{~mm}$ 挙上し, その㖽位をそれぞれ， V.D. +1 , V.D. +2 , V.D. +4 , V.D. +6 とした. ま た，咬合高径を垂直的に $1 \mathrm{~mm}, 2 \mathrm{~mm}, 4 \mathrm{~mm}$ 減少さ せた顎位をそれぞれ，V.D. $-1 ，$ V.D. $-2 ，$ V.D. -4 とした.

被験者を歯科用治療椅子にカンペル平面が沐面と平行
となるように座らせ，安頭台により頭部を安定させた。 その後, M.K.G. を通法に従って装着した.

\section{3 . 測定項目}

本実験の被験者は，すれ違い咬合者であり，咬合高佳 を減少させることが可能である，そこで，訟合高径を挙 上させた場合と同様, 減少させた場合についても, 各顎 位におけるタッピングポイントの前後的偏位量, 左右的 偏位量, タッピングエリア，タッピングポイントのばう つきについて調べた。

a . 咬合高径を変化させた場合のタッピングポイントの 前後的偏位量, 左右的偏位量

V.D. -4 , V.D. -2 , V.D. -1 , V.D. \pm 0, V.D. + 1, V.D. +2, V.D. +4 , V.D. +6 の各顎位で50回夕ッ ピング運動を行わせ, 中心位を基準として, 前後的偏位 量, 左右的偏位量を求めた.

b . 咬合高径を変化させた場合のタッピングエリアの変 化

V.D. -4 , V.D. -2 , V.D. -1 , V.D. \pm 0 , V.D. + 1, V.D. +2 , V.D. +4 , V.D. +6 の各顎位で50回夕 ッピング運動を行わせ，得られたデータををとに，タッ ピングェリアを算出した.

c．各顝位におけるタッピングポイントの前後的ばらつ きと左右的ばらつき

タッピングポイントのばらつきの程度が, 前後的に大 きいのか，あるいは，左右的に大きいのかを知るため に, 各罰位における前後的偏位と左存的偏位の分散の比 の検定を行った。

\section{実 験 結 果}

\section{I . 実験 I}

A. 中心咬合位でのタッピングポイントの前後的偏位 量, 左右的偏位量, タッピングエリア

表 5 は, 中心咬合位でのタッピングポイントの測定結 果である. 前後的偏位量は, 最大前方 $0.05 \pm 0.12 \mathrm{~mm}$, 後方 $0.29 \pm 0.13 \mathrm{~mm}$, 平均では後方に $0.09 \pm 0.10 \mathrm{~mm}$ で あり, 左右的偏位量は, 最大右側 $0.13 \pm 0.06 \mathrm{~mm}$, 左側 $0.21 \pm 0.10 \mathrm{~mm}$, 平均では右側に $0.01 \pm 0.07 \mathrm{~mm}$ であっ た。 まだ,タッピングエリアは, 最大 $0.06 \mathrm{~mm}^{2}$, 最小 $0.00 \mathrm{~mm}^{2}$, 平均 $0.02 \pm 0.02 \mathrm{~mm}^{2}$ であった.

問㟝に基づき記録した習慣性咀嚼側については，左右 側でちらか明確であった者が，20名中14名 $(70.0 \%)$ で あり，両側咀嚼者は 20 名中 6 名 $(30.0 \%)$ であった。つ ぎに，習慣性咀嚼側とタッピングポイントの偏位側との 関係についてみると, 14名の片側咀噮者のうち, 習慣性 
表 5 中心咬合位でのタッピングポイントの偏位量 とタッピングエリア

\begin{tabular}{|c|c|c|c|c|}
\hline 被験者 & $\begin{array}{l}\text { 前後的 } \\
\text { 偏位量 }\end{array}$ & $\begin{array}{l}\text { 左右的 } \\
\text { 偏位量 }\end{array}$ & $\begin{array}{l}\text { タッピン } \\
\text { グエリア }\end{array}$ & $\begin{array}{l}\text { 習慣性 } \\
\text { 勗嚼側 }\end{array}$ \\
\hline 1 & +0.05 & 0.00 & 0.05 & Both \\
\hline 2 & -0.29 & -0.06 & 0.02 & Both \\
\hline 3 & -0.28 & -0.05 & 0.03 & Both \\
\hline 4 & +0.04 & -0.05 & 0.05 & Both \\
\hline 5 & -0.04 & -0.03 & 0.02 & Right \\
\hline 6 & -0.16 & +0.07 & 0.03 & Right \\
\hline 7 & -0.19 & +0.13 & 0.01 & Right \\
\hline 8 & -0.07 & -0.02 & 0.01 & Both \\
\hline 9 & -0.07 & +0.07 & 0.01 & Left \\
\hline 10 & +0.03 & +0.04 & 0.02 & Right \\
\hline 11 & 0.00 & +0.02 & 0.01 & Right \\
\hline 12 & -0.02 & +0.03 & 0.00 & Right \\
\hline 13 & -0.05 & +0.02 & 0.00 & Both \\
\hline 14 & -0.08 & +0.06 & 0.01 & Left \\
\hline 15 & -0.14 & +0.01 & 0.04 & Right \\
\hline 16 & -0.01 & -0.21 & 0.02 & Left \\
\hline 17 & -0.14 & -0.01 & 0.01 & Right \\
\hline 18 & -0.16 & -0.02 & 0.00 & Right \\
\hline 19 & -0.19 & +0.05 & 0.06 & Right \\
\hline 20 & -0.08 & +0.10 & 0.01 & Right \\
\hline 平均 & -0.09 & +0.01 & 0.02 & \\
\hline 䅺準偏差 & 0.10 & 0.07 & 0.02 & \\
\hline
\end{tabular}

$$
\begin{aligned}
& \text { 前後的偏位量 篻位： } \mathrm{mm} \\
& + \text { : 前方 } \\
& \text { - : 後方 } \\
& \text { 左右的偏位量 单位: } \mathrm{mm} \\
& + \text { : 右側 } \\
& \text { - : 左侧 } \\
& \text { タッピングエリア 単位: } \mathrm{mm}^{2}
\end{aligned}
$$

咀嚼側とタッピングポイントの偏位側とが一致した者は 9 名 $(64.3 \%)$ であり，不一致の者は 5 名 $(35.7 \%)$ で あった。

B . 咬合高径を変化させた場合のタッビングポイントの 前後的偏位量, 左右的偏位量

表 $6 ， 7$ は, 咬合高径を変化させた場合のタッピング ポイントの前後的偏什量, 左右的偏估量を示している. 表 6 は，V.D. \pm 0 から順に V.D. +10 まで咬合高径を 挙上させた場合の結果であり，表 7 は逆に，V.D. +10 から順に V.D. \pm 0 まで咬合高径を減少させた場合の結

\begin{tabular}{|c|c|c|c|}
\hline 䫟 位 & $\begin{array}{l}\text { 前後的 } \\
\text { 偏位量 }\end{array}$ & $\begin{array}{l}\text { 左右的 } \\
\text { 偏位量 }\end{array}$ & $\begin{array}{l}\text { タッピン } \\
\text { グエリア }\end{array}$ \\
\hline V.D. +10 & $1.96 \pm 1.60$ & $-0.01 \pm 0.60$ & $0.81 \pm 1.08$ \\
\hline V.D. +8 & $1.54 \pm 1.26$ & $-0.11 \pm 0.51$ & $0.60 \pm 0.80$ \\
\hline V.D. +6 & $1.15 \pm 0.96$ & $-0.08 \pm 0.46$ & $0.34 \pm 0.43$ \\
\hline V.D. +4 & $0.93 \pm 0.80$ & $-0.05 \pm 0.45$ & $0.27 \pm 0.43$ \\
\hline V.D. +2 & $0.68 \pm 0.46$ & $-0.08 \pm 0.34$ & $0.12 \pm 0.15$ \\
\hline V.D. \pm 0 & $0.55 \pm 0.33$ & $-0.02 \pm 0.19$ & $0.02 \pm 0.02$ \\
\hline \multicolumn{4}{|c|}{$\mathrm{n}=20$} \\
\hline \multicolumn{3}{|c|}{ 前後的偏位量 } & 単位: $\mathrm{mm}$ \\
\hline \multicolumn{3}{|c|}{ 左右的偏位量 } & 単位：mm \\
\hline \multicolumn{4}{|c|}{+ : 右側 } \\
\hline \multicolumn{4}{|c|}{ －：左側 } \\
\hline & \multicolumn{2}{|c|}{ タッピングエリア } & 単位： $\mathrm{mm}^{2}$ \\
\hline
\end{tabular}
果である.
表 6 咬合高径の変化とタッピングポイントの偹位量 (有䨓顎者挙上時)

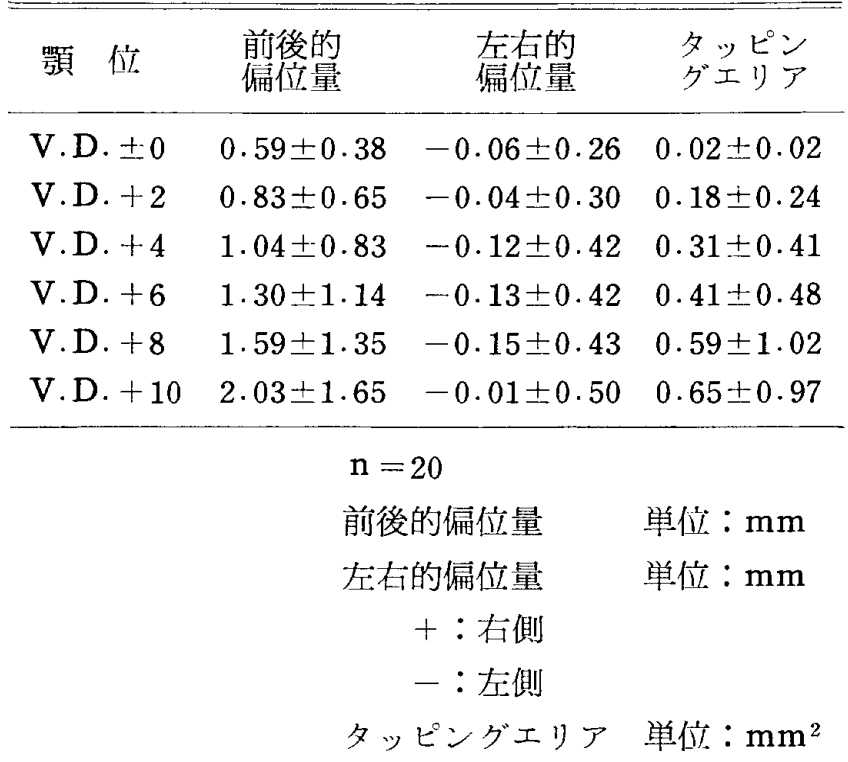

表 7 咬合高径の変化とタッピングポイントの偏位量 (有菊顎者減少時)

前後的偏位量については, 挙上時の最大值はV.D.+

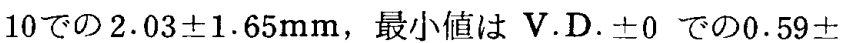
$0.38 \mathrm{~mm}$, 減少時の最大值はV.D. +10 での $1.96 \pm 1.60$

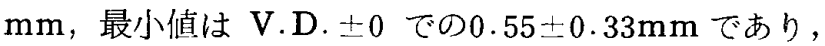
举上時, 娍少㭙ともに, 咬合高径が高くなるに従って, 中心仿からのタッピングポイントの前方偏位量が大きく なる傾向がみられた，そこで，各箱位間で対応のある 2 組の平均値の差の検定を行ったところ，挙上時には， V.D. \pm 0 と V.D. +2 との閏で, 減少時には, V.D. \pm 0 とV.D. +2, V.D. +4 との間で有意苃が認められな 
表 8 各須位での前後的偏位量の対応のある 2 組の平均值の差の検定（有歯顎者挙上時）

\begin{tabular}{llllll}
\hline V.D. +2 & - & & & & \\
V.D. +4 & $*$ & $*$ & $*$ & & \\
V.D. +6 & $* *$ & $* *$ & $* *$ & $*$ & $*$ \\
V.D. +8 & $* *$ & $* *$ & $* *$ & $* *$ \\
V.D. +10 & $* *$ & V.D. +2 & V.D. +4 & V.D. +6 & V.D. +8 \\
\hline & V.D. \pm 0 & & & $*$ 色険率 $5 \%$ で有意
\end{tabular}

表 9 各簤位での前後的偏位量の対応のある 2 組の平均值の差の検定（有歯顎者減少時）

\begin{tabular}{|c|c|c|c|c|c|}
\hline V.D. +2 & - & & & & \\
\hline V.D. +4 & - & $*$ & & & \\
\hline V.D. +6 & $*$ & $* *$ & $*$ & & \\
\hline V.D. +8 & $* *$ & $* *$ & $* *$ & $* *$ & \\
\hline V.D. +10 & $* *$ & $* *$ & $* *$ & $* *$ & $*$ \\
\hline & V.D. \pm 0 & V.D. +2 & V.D. +4 & V.D. +6 & V.D. +8 \\
\hline
\end{tabular}

かったが，他の顎位間では全て有意差が喼められた（表 8，9).すなわち，咬合高径が高くなるに従って，前 後的偏位量が大きくなることがわかった。

つぎに, 左右的偏位量についてみると, 挙上時の最大 值は V.D. +8 での左側へ $0.15 \pm 0.43 \mathrm{~mm}$, 最小值は V.D. +10 での左側 $0.01 \pm 0.50 \mathrm{~mm}$, 減少時の最大值 はV.D. +8 での左側へ0.11士0.51mm, 最小值はV.D. +10 での左側へ $0.01 \pm 0.60 \mathrm{~mm}$ であった．各頡位間で対 応のある 2 組の平均值の差の検定を行ったところ，挙上 時の V.D. +8 と V.D. +10 との間で有意差が認められ たが，他の顎位間では全て有意差が認められなかった （表10，11）。つまり，咬合高径が高くなっても，左右 的には有意な偏位を示さないととがわかった。
挙上時と減少時の前後的偏位量, 左右的偏位量につい て比較を行うと，同一顎位では，近似した值を示してい る.そこで，同一顎位での挙上時，減少時の值につい て, 対応のある 2 組の平均值の差の検定を行ったとこ ろ，全ての顎位で有意差は認められなかった。

C. 茭合高径を変化させた場合のタッピンダエリアの変 化

表 6,7 および図 7 は, 各顎位でのタッピングエリア を示している。挙上時のタッピンダエリアの最大值は V.D. +10 での $0.65 \pm 0.97 \mathrm{~mm}^{2}$, 最小值はV.D. \pm 0 で の $0.02 \pm 0.02 \mathrm{~mm}^{2}$ であり，盿合高径を挙上するに良っ て，タッピングエリアは明らかに広くなった。一方，娍 少時のタッピングエリアの最大值はV.D. +10 での0.81

表10 各顎位での左右的偏位量の刘応のある 2 組の平均值の差の検定（有蒾顎者挙上時）

\begin{tabular}{|c|c|c|c|c|c|}
\hline V.D. +2 & - & & & & \\
\hline V.D. +4 & - & - & & & \\
\hline V.D. +6 & - & - & - & & \\
\hline V.D. +8 & - & - & - & - & \\
\hline \multirow[t]{2}{*}{ V.D. +10} & - & - & - & - & * \\
\hline & V.D. \pm 0 & V.D. +2 & V.D. +4 & V.D. +6 & V.D. +8 \\
\hline
\end{tabular}


表11 各額位での左右的偏位量の対応のある 2 組の平均值の差の検定 (有㐘顎者減少時)

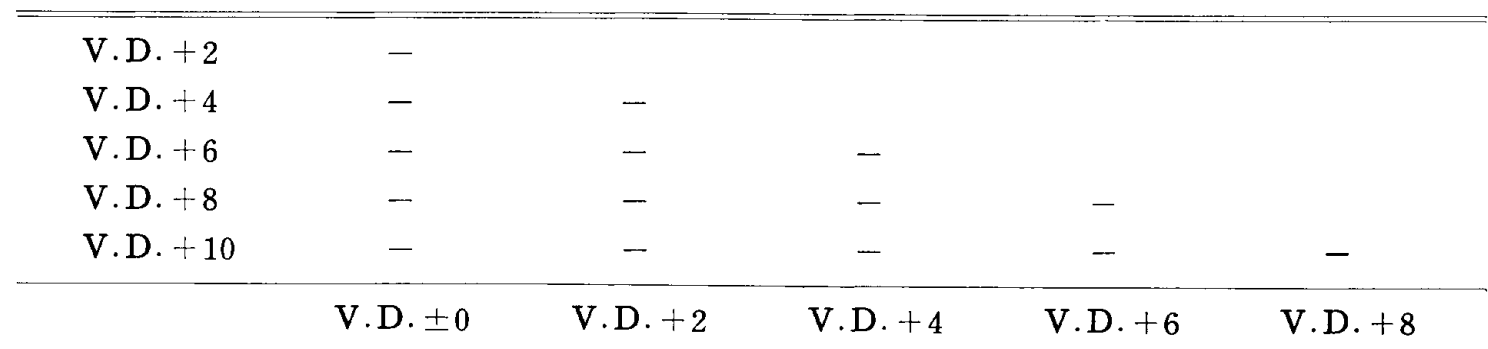

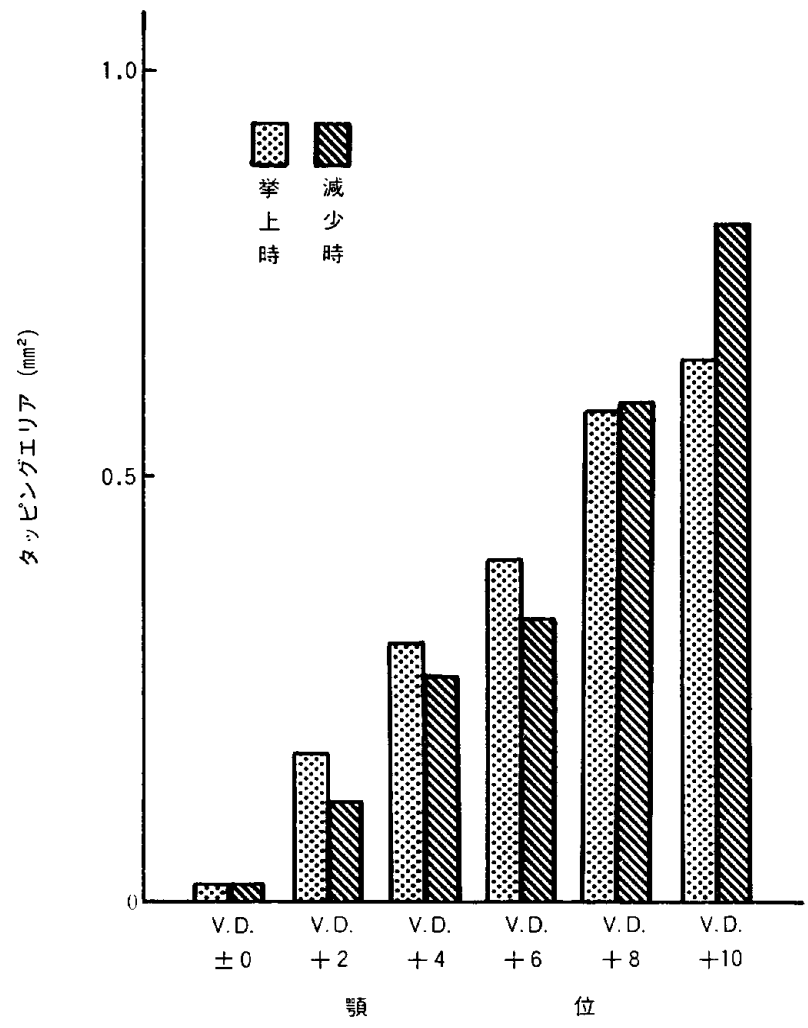

困 7 有㐘顩者での各顝位におけるタッピングエリア $(\mathrm{n}=20)$

$\pm 1.08 \mathrm{~mm}^{2} ，$ 最小值はV.D. \pm 0 での $0.02 \pm 0.02 \mathrm{~mm}^{2}$ であり，挙上時と同様，咬合高径が高いほど，タッピン
グエリアも広くなる傾向がみられた，そこで，各顩位間 で刘忍のある 2 組の平均值の差の検定を行ったところ， 表 12,13 亿示すような結果を得た。すなわち,挙上時，減 少時ともにV.D. \pm 0 と V.D. +2 亿ついては, 他の全 ての筫位との間に有意差が認められた。しかし，挙上時 では, V.D. +4 と V.D. +6, V.D. +4 と V.D. +8 , V.D. +6 と V.D. +8, V.D. +8 と V.D. +10 との間 に, 减少時では, V.D. +4 と V.D. +6, V.D. +8 と V.D. + 10 との間に有意差が認められなかった。

つぎに，挙上時のタッピングエリアと減少時のタッピ ングエリアとを各頡位で比較した。V.D. \pm 0 では, 挙 上時, 減少時ともに同值であったが, V.D. +2 , V.D. +4, V.D. +6 では学上時の方が大きな值を示し, 逆 亿, V.D. +8, V.D. +10 では減少時の方が大きな值を 示した. そこで，挙上時と減少時の同一顎位での值につ いて，対応のある 2 組の平均值の差の検定を行ったとこ ろ，全ての䫟位で有意差は認められなかった，すなわ ち，挙上時，減少時ともに，同一盿合高径では，ほぼ近 似したタッピングエリアを示しているてとになる。

D. 各顎位におけるタッピングポイントの前後的ばらつ きと左右的ばらつき

各靧位で, 前後的偏位々左右的偏位の分散の比の検定 を行った結果が，表14，15である.表14は挙上時の結果 で，前後的ばらつきが有意に大きかった者は，最大 75.0

表12 各靧位でのタッピングエリアの対応のある 2 組の平均值の差の検定（有㐘钼者挙上時）

\begin{tabular}{lllll}
\hline \hline V.D. +2 & $* *$ & & & \\
V.D. +4 & $* *$ & $*$ & & \\
V.D. +6 & $* *$ & $* *$ & - & \\
V.D. +8 & $*$ & $* *$ & $* *$ & $*$ \\
V.D. +10 & $* *$ & V.D. +2 & V.D. +4 & V.D. $+6 \quad$ V.D. +8 \\
\hline & V.D. +0 & & $*$ 危険率 $5 \%$ \%゙有意 \\
\hline
\end{tabular}


表13 各顎位でのタッピングエリアの対応のある 2 組の平均值の差の検定（有米顎者減少時）

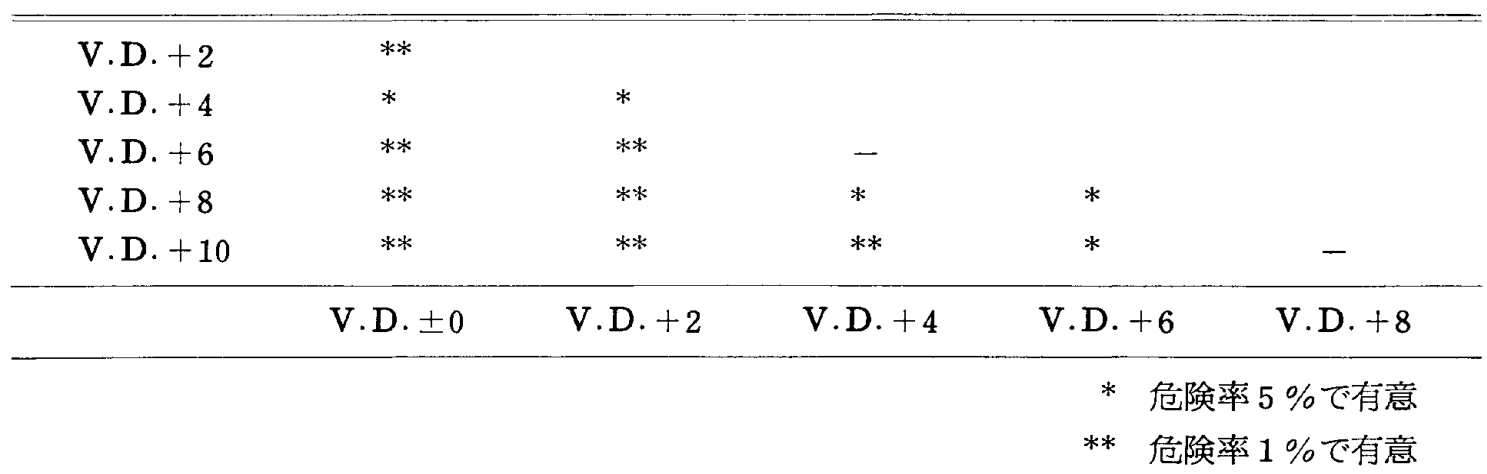

表14 各額位での前後的ばらつきと左右的ばらつきの比較（有歯顎者挙上時）

\begin{tabular}{|c|c|c|c|c|c|c|}
\hline \multirow{2}{*}{ 被験者 } & \multicolumn{4}{|c|}{ 顎 } & \multicolumn{2}{|l|}{ 位 } \\
\hline & V.D. \pm 0 & V.D. +2 & V.D. +4 & V.D. +6 & V.D. +8 & V.D. +10 \\
\hline 1 & \pm & - & \pm & - & - & + \\
\hline 2 & + & + & + & \pm & \pm & + \\
\hline 3 & + & + & \pm & + & \pm & + \\
\hline 4 & + & + & + & + & + & + \\
\hline 5 & \pm & + & + & + & \pm & - \\
\hline 6 & + & + & + & - & + & + \\
\hline 7 & \pm & \pm & + & \pm & \pm & \pm \\
\hline 8 & \pm & + & + & + & + & + \\
\hline 9 & + & - & \pm & + & \pm & - \\
\hline 10 & - & \pm & + & + & + & + \\
\hline 11 & + & + & + & + & + & + \\
\hline 12 & + & + & + & + & + & + \\
\hline 13 & + & + & + & + & + & + \\
\hline 14 & + & + & + & + & + & + \\
\hline 15 & + & - & - & + & \pm & \pm \\
\hline 16 & - & + & \pm & \pm & + & + \\
\hline 17 & + & + & + & + & + & + \\
\hline 18 & \pm & \pm & \pm & \pm & \pm & \pm \\
\hline 19 & + & + & + & + & + & + \\
\hline 20 & - & \pm & + & \pm & + & + \\
\hline$+*$ & 60.0 & 65.0 & 70.0 & 65.0 & 60.0 & 75.0 \\
\hline - * & 15.0 & 15.0 & 5.0 & 10.0 & 5.0 & 10.0 \\
\hline $\pm *$ & 25.0 & 20.0 & 25.0 & 25.0 & 35.0 & 15.0 \\
\hline
\end{tabular}

* 単位: \%

$95 \%$ 信頼度での比較

+ ：前後的ばらつき>左右的ばらつき

一：前後的ばらつきく左左的ばらつき

士：有意差なし 
表15 各瓄位での前後的ばらつきと左右的ばらつきの比較（有歯顎者減少時）

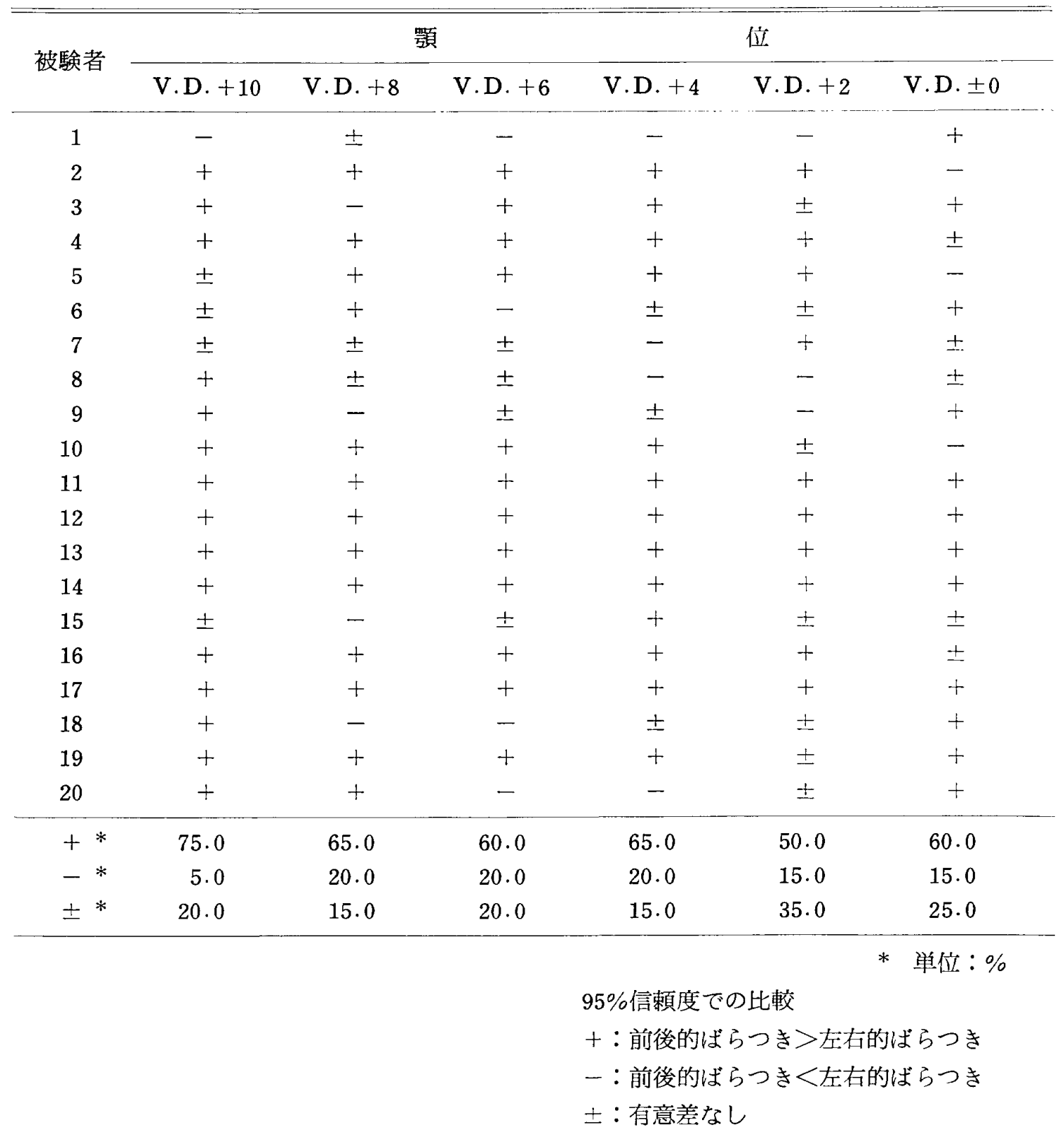

$\%($ V.D. +10$)$ ，最小 $60.0 \%$ (V.D. \pm 0, V.D. +8 ), 平均 $65.8 \%$ であり，一方，左右的ばらつきが有意に大き かった者は，最大 $15.0 \%$ (V.D. $\pm 0 ，$ V.D. +2)，最小 $5.0 \%$ (V.D. +4, V.D. +8 ), 平均 $10.0 \%$ であった. また，前後的ばらつきと左右的ばらつきとの間に有意差 が認められなかった者は，最大 $35.0 \%$ (V.D. +8 )，最 小 $15.0 \%(\mathrm{~V} . \mathrm{D} .+10)$, 平均 $24.2 \%$ であった.

表15は減少時の結果であり，挙上時とほぼ同様の傾向 を示している，すなわち，前後的ばらつきが有意に大 きかった者は，最大 $75.0 \%$ （V.D.+10），最小 $50.0 \%$ (V.D. +2), 平均 $62.5 \%$ であり, 左右的ばらつきが有 意に大きかった者は，最大 $20.0 \%$ (V.D. +8，V.D.十
6, V.D. +4$)$ ，最小 $5.0 \%($ V.D. +10$)$ ，平均 $15.8 \%$ で あったまた，前後的ばらつきと左右的ばらつきとの間 に有意差が認められなかった者は，最大 $35.0 \%$ (V.D. +2 ），最小 $15.0 \%$ (V.D. +4, V.D. +8 ），平均 $21.7 \%$ であった。

このように，挙上時，減少時ともに，全ての額位でほ ぼ同様の傾向が認められ，前後的ばらつきが有意に大き かった者は，挙上時，減少時を平均すると $64.2 \%$ であ り，左右的ばらつきが有意に大きかった者は，派均 12.9 \%であった。

\section{II . 実験 II}

A . 咬合高径を変化させた場合のタッピングポイントの 
表16 咬合高径の変化とタッピングポイントの偏位量 (義歯装着者)

\begin{tabular}{|c|c|c|c|}
\hline 顎 位 & $\begin{array}{l}\text { 前後的 } \\
\text { 偏位量 }\end{array}$ & $\begin{array}{l}\text { 左右的 } \\
\text { 偏位量 }\end{array}$ & $\begin{array}{l}\text { タッピン } \\
\text { グエリア }\end{array}$ \\
\hline V.D. -4 & $0.33 \pm 0.17$ & $+0.06 \pm 0.22$ & $0.05 \pm 0.04$ \\
\hline V.D. -2 & $0.43 \pm 0.25$ & $+0.11 \pm 0.21$ & $0.06 \pm 0.09$ \\
\hline V.D. -1 & $0.48 \pm 0.26$ & $+0.09 \pm 0.16$ & $0.05 \pm 0.06$ \\
\hline V.D. \pm 0 & $0.46 \pm 0.29$ & $+0.16 \pm 0.30$ & $0.06 \pm 0.08$ \\
\hline V.D. +1 & $0.51 \pm 0.31$ & $+0.09 \pm 0.34$ & $0.10 \pm 0.10$ \\
\hline V.D. +2 & $0.53 \pm 0.26$ & $+0.21 \pm 0.34$ & $0.10 \pm 0.09$ \\
\hline V.D. +3 & $0.80 \pm 0.55$ & $+0.11 \pm 0.41$ & $0.19 \pm 0.23$ \\
\hline V.D. +4 & $1.09 \pm 0.74$ & $+0.32 \pm 0.53$ & $0.39 \pm 0.46$ \\
\hline \multicolumn{4}{|c|}{$\mathrm{n}=13$} \\
\hline \multicolumn{3}{|c|}{ 前後的偏位量 } & 単位：mm \\
\hline \multicolumn{3}{|c|}{ 左右的偏位量 } & 単位：mm \\
\hline \multicolumn{4}{|c|}{+ : 死側 } \\
\hline \multicolumn{4}{|c|}{-：左側 } \\
\hline \multicolumn{4}{|c|}{ タッピングエリア } \\
\hline
\end{tabular}

前後的偏位量, 左右的偏位量

表16は，すれ違い咬合者で咬合高径を増減させた場命 のタッピングポイントの前後的偏位量, 左右的偏位量を ボしている。

前後的偏位量についてみると，最大值はV.D. +6 で の $1.09 \pm 0.74 \mathrm{~mm}$, 最小值はV.D. -4 での $0.33 \pm 0.17$ $\mathrm{mm}$ であり，咬合高径が高くなるに従って，大きな值と なったそこてで，各顎位間で対応のある 2 組の平均值の 差の検定を行ったところ，表17亿示すような結泟となっ た.すなわち，V.D. \pm 0 と V.D. +6 との間では有意 差が認められたが，V.D. \pm 0 と他の頻位との闎では， 有意差が認められなかった。

左右的偏位量についてみると, 最大値はV.D. +6で の左側へ $0.32 \pm 0.53 \mathrm{~mm}$, 最小值はV.D. -4 での右側

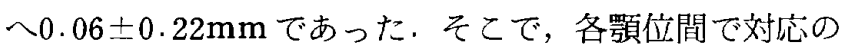
ある 2 組の平均值の差の検定を行ったとてろ, 表18に示 すような結果となった.すなわち，V.D. +4 と V.D. +6 との間で有意差が認められたが, 他の全ての顩位間 では, 有意差が認められなかった。

表17 各顎位での前後的偏位量の対応のある 2 組の平均值の差の検定（義蒾装着者）

\begin{tabular}{lllllllll}
\hline V.D. -2 & - & & & & & & \\
V.D. -1 & $*$ & - & & & & & \\
V.D. \pm 0 & - & - & - & & & & \\
V.D. +1 & $*$ & - & - & - & & \\
V.D. +2 & $*$ & - & - & - & - & \\
V.D. +4 & $* *$ & $*$ & $*$ & - & - & - & \\
V.D. +6 & $* *$ & $*$ & $* *$ & $*$ & $*$ & $*$ & - \\
\hline & V.D. -4 & V.D. -2 & V.D. -1 & V.D. \pm 0 & V.D. +1 & V.D. +2 & V.D. +4 \\
\hline & & & & & & & $*$ & 危険率 $5 \%$ \%゙有意 \\
\hline
\end{tabular}

表18 各澦位での左右的偏位量の対応のある 2 組の平均值の差の検定（義㐘装着者）

\begin{tabular}{lllllllll}
\hline V.D. -2 & - & & & & & & \\
V.D. -1 & - & - & & & & & \\
V.D. \pm 0 & - & - & - & & & & \\
V.D. +1 & - & - & - & - & & & \\
V.D. +2 & - & - & - & - & - & & \\
V.D. +4 & - & - & - & - & - & - & $*$ \\
V.D. +6 & - & - & - & - & - & - & $*$ \\
\hline & V.D. -4 & V.D. -2 & V.D. -1 & V.D. \pm 0 & V.D. +1 & V.D. +2 & V.D. +4 \\
\hline
\end{tabular}


B . 咬合高径を変化させた場合のタッピングエリアの変 化

表16および図 8 は，すれ違い咬合者 13 名より得られ た，各頡位でのタッピングエリアを示しているＶ.D. \pm 0 での值を基準として見た場合，咬合高径をさげた各 顗位での值については，著明な変化は認められなかっ た。一方，咬合高径をあげた各顥位での值については， 咬合高径を挙上するに従って大きな值を示し, 最大值 は, V.D. +6 での $0.39 \pm 0.46 \mathrm{~mm}^{2}$ であった. 表19は, 各靧位間で対応のある 2 組の平均值の差の検定を行った 結果を示している. V.D. \pm 0 と V.D. +1 , V.D. -1 , V.D. -2, V.D. -4 との間では, 有意差は認められな かったが，V.D. \pm 0 とV.D. +2, V.D. +4, V.D. +6 との間では有意差が認められた。すなわち，適正咬合高 徍よりも $2 \mathrm{~mm}$ 以上㕮合高径が高くなると、タッピング エリアは有意に広くなった。

C．各頜位におけるタッピングポイントの前後的ばらつ きと左右的ばらつき

表20は，各㖽位での前後的偏位と左右的偏位の分散の 比の検定を行った結果である．前後的ばらつきが有意に

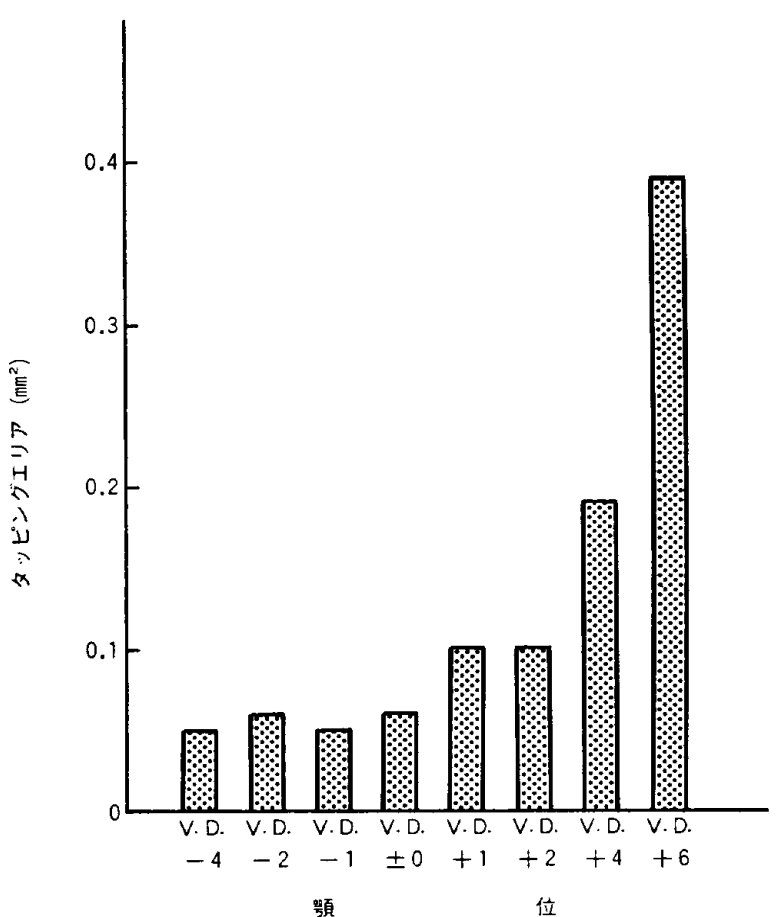

図 8 義歯装着者での各買位におけるタッピングエリア $(n=13)$

表19 各須位でのタッピングエリアの対応のある 2 組の平均值の差の検定（義菡装着者）

\begin{tabular}{|c|c|c|c|c|c|c|c|}
\hline V.D. -2 & - & & & & & & \\
\hline V.D. -1 & - & - & & & & & \\
\hline V.D. \pm 0 & - & - & - & & & & \\
\hline V.D. +1 & - & - & $*$ & - & & & \\
\hline V.D. +2 & $* *$ & - & $*$ & $* *$ & - & & \\
\hline V.D. +4 & * & * & * & * & - & - & \\
\hline \multirow[t]{2}{*}{ V.D. +6} & $*$ & $*$ & $*$ & $*$ & $*$ & $*$ & $*$ \\
\hline & V.D. -4 & V.D. -2 & V.D. -1 & V.D. \pm 0 & V.D. +1 & V.D. +2 & V.D. +4 \\
\hline
\end{tabular}

大きかった者は，最大 $53.8 \%$ (V.D. -1, V.D.+2，た。

V.D. +6 ), 最小 $38.5 \%$ (V.D. -4, V.D. \pm 0, V.D. $+1)$ ，平均 $46.1 \%$ 認められた。一方，左右的ばらつきが 有意に大きかった者は，最大 $30.8 \%$ (V.D. \pm 0$) ，$ 最小 $7.7 \%$ (V.D. -4, V.D. -2 , V.D. +2 , V.D. +4, V. D. +6$)$, 平均 $13.5 \%$ であった. また前後的ばらつきと 左右的ばらつきの間に有意差が認められなかった者は, 最大 $53.8 \%$ (V.D. -4), 最小 $30.8 \%$ (V.D. -1, V.D. $\pm 0)$, 平均 $40.4 \%$ であった.

すなわち，義歯装着者に扔いても有曾影者同様，夕 ッピングポイントが前後的にばらつく傾向が認められ

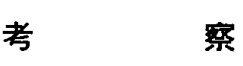

適切な上下顎の水平的対位関係を決定することは，蒾 科補緅臨床において，非常に重要なステップである，有 米頱者で峧合する蒾牙が存在する場合には，比較的簡単 に，しかも，正確に決定することができるが，無菌頱者 では，簡単に決定あるいは確認することはできない，そ てで，臨床的に種々の方法が提唱されているが，上く用 いられる方法として，タッピング運動を利用し得られた 習慣性閉口位に中心咬合位を設定する方法がある。 
表20 各顩位での前後的ばらつきと左右的ばらつきの比較（義荬装着者）

\begin{tabular}{ccccccccc}
\hline \hline \multirow{2}{*}{ 被験者 } & \multicolumn{7}{c}{ 顎 } & \multicolumn{5}{c}{ 位 } \\
\cline { 2 - 8 } & V.D. -4 & V.D. -2 & V.D. -1 & V.D. \pm 0 & V.D. +1 & V.D. +2 & V.D. +4 & V.D. +6 \\
\hline 1 & + & + & + & + & + & + & + & + \\
2 & + & + & + & + & + & + & + & + \\
3 & \pm & + & + & \pm & \pm & - & \pm & \pm \\
4 & \pm & \pm & - & - & \pm & + & + & + \\
5 & - & - & \pm & - & - & + & - & \pm \\
6 & \pm & \pm & \pm & \pm & \pm & \pm & \pm & - \\
7 & + & + & + & + & + & + & + & + \\
8 & + & \pm & + & + & + & + & + & \pm \\
9 & \pm & \pm & - & \pm & \pm & \pm & \pm & + \\
10 & + & + & \pm & - & - & \pm & \pm & \pm \\
11 & \pm & + & + & \pm & - & \pm & \pm & + \\
12 & \pm & \pm & + & + & \pm & + & + & + \\
13 & \pm & \pm & \pm & - & + & \pm & \pm & \pm \\
\hline${ }^{*}$ & 38.5 & 46.2 & 53.8 & 38.5 & 38.5 & 53.8 & 46.2 & 53.8 \\
$-*$ & 7.7 & 7.7 & 15.4 & 30.8 & 23.1 & 7.7 & 7.7 & 7.7 \\
$\pm *$ & 53.8 & 46.2 & 30.8 & 30.8 & 38.5 & 38.5 & 46.2 & 38.5 \\
\hline
\end{tabular}

* 単位: \%

95\%信頼度での比較

$+：$ 前後的ばらつき>左右的ばらつき

一：前後的ばらつき<左右的ばらつき

士：有意差なし

そこで，咬合採得時にタッピング運動を利用するとと について検討を試みた。

\section{I . 研究方法}

タッピングポイントを記録計测する方法としては，金 属プレート上にタッピングポイントを記録し，それを写 真撮影する方法 ${ }^{2}$, 16)，あるい梳，万能投影器を用いて

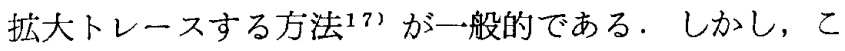
れらの方法でタッピングポイントを記録すると，タッピ ングポイントが重なってしまい，1つ1つの位置を判読 することが困難である．そてで，本研究では，M.K.G. に 2 pen recorder を接続し, タッピング運動を掃引 記録することにより，各タッピングポイントの前後的偏 位量, 左右的偏位量を計測した。

M.K.G. は，磁場の強さの変化を電気的に変換する 方法を利用した下顎運動記録装置である。しかし，下顎 切橉点の移動距離と磁束の変化量とは, 非直線的な関係 にあるため，装置自体の特性に起因する像の歪が生じる 18-20)。 そこで，実験に先立ち，M.K.G.の精度につ いて検討したところ, 本装置の分解能は $0.04 \mathrm{~mm}$ であ
り，水平面内での 最大誤差は，原点を中心に 磁石の 2 $\mathrm{mm}$ 移動時で, 前後方向 $5.0 \%$, 左右方向 $2.8 \%$ であり, $4 \mathrm{~mm}$ 移動時では, 前後方向 $6.0 \%$, 左右方向 $3.4 \%$ であ った.

分解能については, 三谷ら $(1977)^{18)}$ の值 $0.05 \mathrm{~mm}$, 川口ら $(1978)^{199}$ の值 $0.07 \mathrm{~mm}$ と比較して, やや小さな 值であった。乙れは三谷ら，川口らが，ブラウン管オシ ロスコープ上の記録を写真撮影して判定したのにたい し, 著者は, M.K.G. に X-Y recorder を接続し, ファイバーペンで記録を行い，判定したためと考えられ る.

像の歪について，川口ら (1978) ${ }^{19}$ は, 歪が5\%を越 えない範囲は, 原点より各方向に $2.0 \mathrm{~mm}$ までの範围で あり，左右方向は歪を伴うととが少ないと報告してお り，てれは，著者の結果と一致している。

以上のことから，タッピングポイントの水平面内での ばらつきを計測するのに，M.K.G.は，十分な精度を 有しているものと思われる.

一方, タッピングポイントの範囲についてみた場合, 
その目安の 1 つとして, 従来からタッピングエリアが求 められている，雨宮ら $(1970)^{15}$ 'は，橎本範囲に注目 乙，前後，左右方向の最大，最小を囲んだ長方形を求 め, タッピングポイントの範囲を比較検討しており，櫻 井 $(1981)^{211}$ は，X-Y recorder 上に記録されたタッ ピングポイントの最外側点を直線でつなぎ，それ化よっ て囲まれた区域を算出し，タッピングエリアとしてい る、しかし，標本範用でデータのばらつきを比較する方 法は，デー夕数が増すと範囲も広くなるため，データ数 が10個以上の時には，不適当であると言われている。ま た，本研究では，データの記録に 2 pen recorder を 用いており，櫻井の方法でタッピングエリアを算出する ためには，データをもとに作図を行わなければならな い，そこで，著者は，タッピングポイントの範用を客観 的に表現するため，50回のタッピングポイントの前後成 分の標準偏差 $\mathrm{a}$ と左石成分の標準偏差 b と注目し, $2 \mathrm{a} \times 2 \mathrm{~b}$ をタッピングエリアとして算出した。

タッピング運動を行わせる際，ストロークを規定して 一定のリズムで行わせる場合と，患者の生理的運動を重 視して患者固有のストロークで行わせる場合とがある．

Widmalm ら $(1977)^{22)}$ は，タッピング運動時の咬筋 活動を筋電図で記録検討し，その結果，毎秒 2 回のリズ 厶に比らへ，毎秒 4〜 6 回のリズムでは，咬筋の活動時 間は短かく，将らつきも大きいと報告している。また， 林 $(1980)^{23)}$ は, 正常有菌顎者を対象として，タッピン グ速度を遅速（毎秒 $0.1 \sim 0.9$ ストローク），中速（毎秒 0.9 1.6ストローク)，急速（每秒1.6〜4.0ストローク） に規定して実験を行った結果，中速でタッピング運動を 行わせた場合が，最もばらつきが少なく安定したと述心 ている，そてで，タッピングストロークを規定すること による影響について検討したところ，被験者固有のス卜 ロークでタッピング運動させた場合とストロークを毎利 1 回，2回，3 回と規定した場合とで，有意差は認めら れなかった。これは，規定した速さが，被験者固有の夕 ッピングストローク（平均毎秒1.4〜2.7回）に比較的近 い速さであったためと思われる，従って，タッピングス トロークを規定するというととよりも，規定した速さが どの程度であるかが問題であり，非常に速く，あるい は，非常に摆くタッピング運動させた場合には，タッピ ングポイントの前後的偏位量, 左右的偏位量, タッピン グエリアが大きくなるものと思われる．

タッピング運動時，口腔感覚を支配する神経からの情 報が，中权プログラムに働きかけ，たえずその動作様式 を修正し，円滑なタッピング運動が遂行されていると考
えられており 24)，咬合高径保持装置を口腔内一装着する ことにより, 口腔感覚が変化し，タッピング運動に何ら かの影響を及ぼすことも考えられる。しかし，咬合高径 を挙上していない状態で，咬合高径保持装置を装着せず タッピング運動をさせた場合と，装着してタッピング運 動をさせた場合とで，タッピングポイントの前後的偏位 量, 左右的偏位量, タッピングエリアに有意差は認めら れなかった．すなわち，下顎プレート後縁を第 2 大曰雨 中央付近に設定し, かつ, 装置を可能な限り小さくし て，舌房の侵害を最小限にとどめたため，咬合高径保持 装置装着による違和感が，比較的少なかったことが予想 される。

また，スタイラスの傾斜については，強い力でタッピ ング運動をさせた場合に，タッピングエリアの位置に影 響を及ぼすととが報告されている25)。しかし，本実験 では,タッピング運動について，被験者们何ら指示を与 えておらず, そのため，スタイラスの傾斜によりタッピ ングポイントの前後的偏位量, 左右的偏位量, タッピン グエリアに何らかの影響があることが予想された，その ため，スタイラスの傾斜の影響について央験を行った が，傾斜による影響は認められなかった。すなわち，七刀 㐘部で $10 \mathrm{~mm}$ 挙上時に，スタイラスはプレートに対して 約 6 度傾斜しているといわれており ${ }^{26)}$ ，その值が比較 的小さいために，スタイラスの傾斜による影響が認めら れなかったものと思われる。

\section{II. 実験結果}

\section{A. 宇験 I}

タッピング運動時に，下顎が直接中心咬合位へ閉口す るととは比較的少ないと言われており，その水平的なず れ沉いて，川口（1968， ${ }^{27}$ は，前後的には後方へ平均 $0.12 \mathrm{~mm}$, 左有的には左倒入平均 $0.06 \mathrm{~mm}$ であると報告 している，著者の結果でも，中心咬合位とタッピングポ イントの間に水平的なずれが認められた．すなわち，前 後的偏位については, 前方偏位を示した者が 3 名, 後方 偏位を示した者が16名，前後的偏位を示さなかった者は わずかに 1 名のみであった：また，その值は，前方 0.05 $\mathrm{mm}$ から後方 $0.29 \mathrm{~mm}$ までの間であり, 前後的偏位量の 平均は0.09mmであり，その絶対值の平均は $0.10 \mathrm{~mm}$ で あった，後方への偏位を示した者が多かったことについ ては，頭位の影響が考えられる．頭部を後傾させた場合 には，タッビングポイントは後方へ偏位すると報告され ている23,25,28,291. 本実験では, カンペル平面が床面 と平行になるように頭部を安定させたため, フランクフ ルト平面が床面と平行になるようにした場合と比らべ， 
頭部はやや後傾した状態となる，そのため，タッピング ポイントもやや後方へ偏位したものと思われる. 左石的 偏位については，右側偏位を示した者が11名，左側偏位 を示した者が 8 名であり，偏位が認められなかった者は 1 名のみであった。また，その值は，右側 $0.13 \mathrm{~mm}$ から 左側0. $21 \mathrm{~mm}$ までの閒であり, 左右的偏位量の平均は有 側へ0.01 $\mathrm{mm}$ であり, その絶対值の平均は0.05 mmであ った，以上のてとから，タッピング運動時に，下顎が直 接中心咬合位へ閉口することは少なく, 中心咬合位と夕 ッピングポイントとの間に, 前後的, 左右的ずれが存在 するととがわかった。

また，タッピングエリアについては，平均 $0.02 \mathrm{~mm}^{2}$ と非常に小さな值を示した。 $(1968)^{27}$ は，咬頭嵌 合位を基準とした習慣的閉口運動時の歯牙接触位の分布 範囲が，咬耗の少ない普通の有蒾顎者では，非常に狭い ことを報告している，本実験では，被験者として咬耗が 少なく中心咬合位の安定した者を選択したため，タッピ ングエリアが非常に狭くなったものと思われる。

タッピングポイントの偏位側と習慣性咀嚼側について みると，従来から，その両者が一致するという報告 ${ }^{15}$, 30) と，必ずしも両者間に関連性がないという報告 ${ }^{171}$ と がある、本実験では，両者が一致した者は $64.3 \%$ であ り，タッピングポイントの偏位側と習慣性咀喘側とが一 致する症例が多いことがわかった。

つぎに，有歯顎者で咬合高径を変化させ，タッピング 運動を行わせた時の，タッピングポイントの前後的偏位 量, 左右的偏位量, タッピングエリアについて検討を行

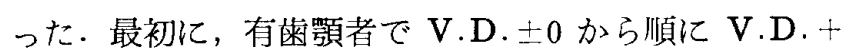
10 まで咬合高径を挙上させた場合と, V.D. +10 から順 に V.D. \pm 0 まで咬合高径を減少させた場合の同一買位 での前後的偏位量, 左右的偏位量, タッピングエリアを 比較した，その結果，全ての顎位で有意差は認められな かった．これは，タッピングポイントの分布範团の前後 径, 左右径について比較を行った丸山（1973）12）の報告 と一致している，すなわち，順次咬合高径を挙上するこ と，あるいは，滅少することによる影響は少なく，咬合 高径が同じ場合, タッピングポイントの前後的偏位量, 左右的偏位量, タッピングエリアは同程度であるものと 思われる。

前後的偏位量, 左右的偏位量についてみた場合, 咬合 高径を挙上するに従って，前後的偏位量が大きくなった のに対し, 左右的偏位量については, 著明な変化は認め られなかった。咬合高径の挙上に伴うタッピングポイン トの前方偏位については, 従来からの報告と一致して

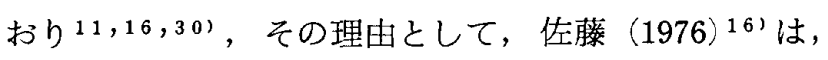
咬合高径挙上時, 閉口筋群はより伸展された状態で, 逆 に，開口筋群はより収縮した状態でタッピング運動を行 わなければならず，顆頭が前方へ移動しやすいというて とをあげている．また，下顎閉口時の運動方向について も，潜在的に前上方へ向かうような機能をもつとされて いる ${ }^{31}$ 。佐久間 $(1959)^{261}$ は, 切歯部で $10 \mathrm{~mm}$ 開口時 に, 顆頭が前方へ $2.0 \mathrm{~mm}$, 下方へ $1.6 \mathrm{~mm}$ 移動すると報 告しており，乙の值が，本実験におけるV.D.+10で の前後的偏位量の平均值と近似していることは與味深 いすすなわち, 咬合高径挙上に伴うタッピングポイント

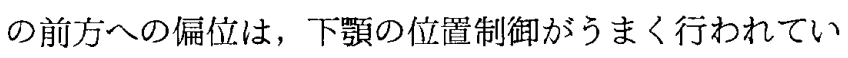
ないととや，咬合高佳挙上による顆頭の前下方への移動 などによるものであろう.

一方, 左右的偏位量に有意差が認められなかったとと については，顎運動の両側性協調がその一因であろう。 阿部 $\left.(1974)^{32}\right)$ は, 額関節桽外側部に密に存在する感覚 受容器により，顆頭の位置および運動に関する情報が中 枢へ伝達されるが，その際，両側性かつ相反的に閉口筋 および開口筋の活動が制御されていると報告されてい る.すなわち，咬合高径を挙上することにより，䫓関 節, 咀嚼筋群などからの情報は変化するが，その左右的 バランスは保たれているものと思われる。

また，有霜顎者の各龥位におけるタッピングエリアを 比較した結果, 咬合高径を挙上するに従って, タッピン グエリアが広くなる傾向が認められた。ててれは，タッピ ングポイントの分布範囲について報告した丸山（1973） ${ }^{12)}$ ，佐藤（1976） ${ }^{16}$ ) の報告と一致している.すなわち, 咬合高径を挙上した場合には,タッピング運動の微細な 位置制御をうまくおてなうことができず，その結果，夕 ッピングエリアが広くなったと考えられる。

つぎに，被験者でとに，各顩位におけるタッピングポ イントの前後的ばらつきと左右的ばらつきとを比較した 結果，左右的ばらつきが有意に大きかった者は，平均 $12.9 \%$ であったのに対し，前後的ばらつきが有意に大 きかった者は，平均 $64.2 \%$ であった，ての結果について は，㗳合高径の変化による影響は認められなかった。す なわち, 咬合高径を挙上した場合に, タッピングポイン 卜の左右的偏位量に有意差が認められなかったととと同 様に, 開口筋群, 閉口筋群の左右的バランスが, 咬合高 径に関係無く保たれているために，前後的ばらつきに比 らべ左右的ばらつきが有意に小さくなったものと考元ら れる。

B . 実験 II 
義歯装着者で, 咬合高径を増減させた場合のタッピン グポイントの前後的偏位量, 左右的偏位量, タッピング エリアについてみると，挙上時には有歯顎者での結果と 同様な傾向を示した.すなわち, 咬合高径を挙上するに 従って, 前後的偏位量は大きくなり, タッピングエリア も広くなったのに反し, 左右的偏位量については, 著明 な変化は認められなかった。しかし，それらの值につい て詳細に検討をおこなってみると, 前後的偏位量につい ては, V.D. \pm 0 と V.D. +1, V.D. +2 との間に有意 差が認められなかった。 また, 有崡顎者の V.D.土0に おける 前後的偏位量 $0.59 \mathrm{~mm}$ (挙上時)，0.55mm（娍 少時）と比較を扢てなうと, 義菌装着者の V.D. \pm 0 で の値 $0.46 \mathrm{~mm}$, V.D. +1 での值 $0.51 \mathrm{~mm}$, V.D. +2 で の值 $0.53 \mathrm{~mm}$ が近似していることがわかる.すなわち， 義霜装着者の V.D. \pm 0, V.D. +1, V.D. +2 でのタッ ピング運動で求められた顎位は, 有歯買当時のタッピン グポイントに近接した位置であるものと思われるま た, 大石 $(1967)^{36)}$ は, 新鮮屍体での顎関節の解剖学的 構造と顆頭位の関係についての研究を行ない, 顆頭安定 位の存在を㸾め, 川畑 $(1971)^{37}$ は, 臨床的顆頭最後位 が, 顆頭安定位に対して $0.11 \sim 1.19 \mathrm{~mm}$, 平均 $0.50 \mathrm{~mm}$ に位置していることを報告している，この傎は，本実験 での中心位とタッピングポイントの前方偏位点との距離 （前方偏位量）と近似した值であり，タッピング運動を 利用して水平的対位関係を決定した場合の顆頭位は, 顆 頭安定位付近であることが予想される。

一方, 咬合高径との関係についてみると, 前後的偏位 量は, V.D. \pm 0 と V.D. +1, V.D. +2 との間で有意 差が認められず, また，タッピングエリアについては, V.D. \pm 0 と V.D.+1 との間で有意差が認められなか った.鵜養 $(1963)^{38}$ は, 総義歯患者の咬合高径について $2 \mathrm{~mm}$ 程度の許容範囲が考えられると報告しており, 馬 場 $(1973)^{39}$ も, 額関節には垂直的要素の許容範囲が存 在すると述べている. 丸山 $(1973)^{32)}$ は, 有蒾疑者で咬 合高径を変化させ，タッピング運動を行わせた結果か ら, 中心咬合位から咬合高径を $3 \mathrm{~mm}$ まで挙上した顎位 まで，タッピングポイントの分布範团に有意差は無く, その間，顆頭は顆頭安定位に位置していると述べてい る，著者の結果もこれらの報告と一致しており，義橉装 着者の咬合高径については, 垂直的に $1 \sim 2 \mathrm{~mm} の$ 許容 範囲が存在し，その範囲内では, 顆頭が顆頭安定位に位 置するものと思われる．

従来から，タッピング運動時の水平的䫩位の 調整に は, 歯根膜受容器からの情報が重要であるとされている

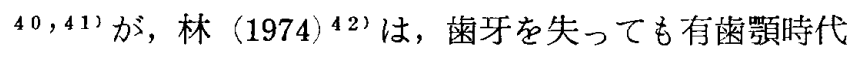
の顎運動に関する筋記憶が残っており，咬合高径が適正 であれば，下顎位が正しく決定できると述べている．ま た，佐藤 $(1976)^{16)}$ は，久損歯数の差がタッピング運動 の巧みさに与える影響は少ないと報告している。著者の 結果では, 義歯装着者の V.D. \pm 0 でのタッピングエリ アが $0.06 \mathrm{~mm}^{2}$ と小さな值であった.V.D. \pm 0 は, 被験 者が現在使用している義夹の咬合高径であり，そのた め, 被験者は, その咬合高径に慣れており, 水平的影位 の調整をうまくおこなうことができたものと思われる。

つぎに，咬合高径をさげた各顎位での結果についてみ ると,タッピングエリアは, 各顎位で近似した值を示し たのに対して, 前後的偏位量, 左右的偏位量について は，咬合高径をさげるに従って，やや小さな值となっ た。しかし，対応のある 2 組の平均值の差の検定の結 果, 有意差は認められなかった。すなわち, 現在使用し ている義菌の咬合高径よりも咬合高径をさげてタッピン グ運動を行わせた場合, 前後的偏位量, 左右的偏位量, タッピングエリアに変化は諗められないことがわかっ

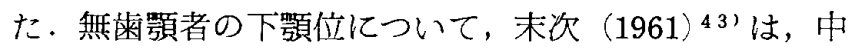
心咬合位よりも上方では，後方限界線にそってほぼ蝶番 的に閉口し，その時の顆頭位は中心位における顆頭位と ほとんど変らないと報告している，従って，咬合高径挙 上時には，顆頭が関節窩から移動した位置でのタッピン グ運動であるのに対し，咬合高径をさげた場合には，顆 頭は関節窩内に存在している.そのため, V.D. \pm 0 で の值と比較して有意差が認められなかったものと思われ る.

被験者ごとに，各顎位におらけるタッピングポイントの 前後的ばらつきと左右的ばらつきとを比較した結果，左 右的ばらつきが有意に大きい者は平均 $13.5 \%$ だったの に対し，前後的ばらつきが有意に大きい者は平均 $46.1 \%$ 認められた。一方, 前後的ばらつきと左有的ばらつきと で有意差が認められなかった者は平均 $40.4 \%$ \%あった。 また，咬合高径の変化による影響は誋められなかった。 これらの結果は, 有画顎者での結果と類似している.す なわち，咬合高径を挙上した場合と同様に，唁合高径 をさげた場合にも，咬合高径に関係無く，開口筋群，閉 口筋群の左右的バランスが保たれているととがわかっ た、また，義䍘装着者で有歯顎者と同様な傾向が示され たことにより，顎運動制御機構において，夹根膜受容器 からの情報以外に, 開口筋群, 閉口筋群などの筋感覚も 重要な要因の1つであるものと思われる.

以上の乙とを総合的に考えると, タッピングポィント 
の前後的偏位量, タッピングエリアは, 咬合高径の適否 を確認するための 1 つの目安となりうるものと思われ る、しかし，その結果のみで咬合高径を決定することは 危険である. 一方, 咬合高径決定後, 水平的対位関係の 決定確認法として，タッピング運動を利用することは有 効であるが，咬合高径を $2 \mathrm{~mm}$ 以上挙上した場合には， タッピングポイントが前方へ偏位する傾向があるので注 意を要する.

\section{結 論}

咬合採得時にタッピング運動を利用することの有效性 を明らかにするため, 有歯顎者 20 名と義蒾装着者 13 名に つて, 咬合高径を変化させ, タッピング 運動を記録 した. その際, Mandibular Kinesiograph に2 pen recorder を接続するととにより，50回のタッピング運 動を重なるととなく，掃引記録した。そのデータをもと に, 各顎位でのタッピングポイントの前後的偏位量, 左 右的偏位量, タッピングエリア，夕ッピングポイントの ばらつきを求めた。

結果は以下のとおりである。

1. 有歯顎者20名における中心咬合位でのタッピング ポイントの前後的偏位量は, 最大前方 $0.05 \pm 0.12 \mathrm{~mm}$,

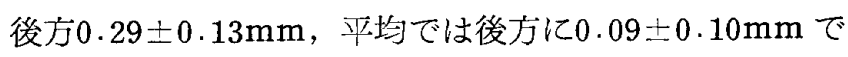
あり, 左右的偏位量は, 最大右側 $0.13 \pm 0.06 \mathrm{~mm}$, 左側

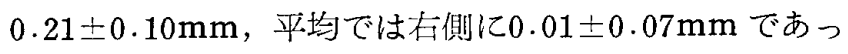
た。また，タッピングエリアは，最大 $0.06 \mathrm{~mm}^{2}$, 最小 $0.00 \mathrm{~mm}^{2}$, 平均0.02 $00.02 \mathrm{~mm}^{2}$ であった。

2 . 有崡龥者でのタッピングポイントの前後的偏位量 は，咬合高徍を挙上するに従って大きくなったが，左在 的偏位量については，有意差が認められなかった。

3. 有歯頭者でのタッピングエリアは, 咬合高径を挙 上するに従って広くなった。

4. 有歯顎者の各顎位におけるタッピングポイントの
前後的ばらつきと左右的ばらつきとを比較した結果, 前 後的ばらつきが有意に大きかった者が平均 $64.2 \%$ 認めら れた。一方, 左右的ばらつきが有意に大きかった者は平 均12.9\%であった。

5. 義雪装着者で咬合高径をさげた各顎位でのタッピ ングポイントの前後的偏位量, 左右的偏位量は, 適正峧 合高径での偏位量（中心位の前方へ0.46士0.29mm, 右 側へ $0.16 \pm 0.30 \mathrm{~mm}$ ) と比較して有意差は認められなか った。

6. 義歯装着者で咬合高径を挙上した場合, 左右的偏 位量については, 有意差が認められなかった．前後的偏 位量については， $4 \mathrm{~mm}$ 挙上顎位まで有意差が認められ なかったが，咬合高径を挙上するに従って大きくなる傾 向を示し， $6 \mathrm{~mm}$ 挙上顎位では有意差が珰められた。

7 . 義歯装着者で咬合高径をさげた各顎位でのタッピ ングェリアについては, 適正咬合高径でのタッピングエ リア $\left(0.06 \pm 0.08 \mathrm{~mm}^{2}\right)$ と比較して, 有意差は䜑めら れなかった。しかし，咬合高径を举上するに従ってタッ ピングエリアは有意に広くなった。

8. 義蒾装着者の各顎位における夕ッピングポイント の前後的ばらつきと左右的ばらつきとを比較した結果， 前後的ばらつきが有意に大きかった者が，平均 $46.1 \%$ 認 められた。一方, 左右的ばらつきが有意に大きかった者 は，平均 $13.5 \%$ であった。

稿を終わるにあたり，終始御愍篤な御指導と御校閲を 賜った恩師豊田静夫教授に対し，心から感謝の意を表す るとともに, 本研究に対し数多くの御援助, 御助言をい ただいた三宅茂樹講師，生理学教室中原敏教授に禹心よ り謝意を捧げます，さらに種々の御協力をいただきまし た補綴学教室員諸兄ならびに心よく本研究の被験者を引 き受けて下さった諸氏に心より感謝いたします。

\section{引用 文 献}

1) 沖野節三：総義粜補経学. 永末書店, 京都, 1972 .

2) Wright, W.H.: Use of intra-oral jaw relation wax records in complete denture prosthesis. J. Am. Dent. Assoc. 26:542-555, 1939.

3 ) Silverman, M.M. : Centric occlusion and jaw relations and fallacies of current concepts. $J$. Prosthet. Dent. 7:750-769, 1957.

4 ) Brill, N., Lammie, G.A., Osbone, J. and Perry, H.T. : Mandibular positions and mandibular movement. Brit. Dent. J. $106: 390-400,1959$.

5) Shanahan, T.E.J.: Physiologic vertical dimension and centric relation. J. Prosthet. Dent. 
$6: 741-747,1956$.

6 Ismail, Y.H. : The consistency of the swallowing technique in determing occlusal vertical relation in edentulous patients. J. Prosthet. Dent. 19:230-236, 1968.

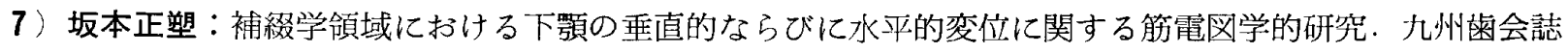
$23: 544-572,1969$.

8 ) Jankelson, B. ・三谷春保・山下 敦・藤井弘之・水泉 猛・崔 富查：Myo-moniter の理論之実際. 歯 界展望 $40: 946-952,1972$.

9）泉谷祐紀員：Myo-pulse によって求められる下顎位の臨床的意義. 補緅誌 $24: 470-485 ， 1980$.

10）川口豊造：無歯買の咬合採得. 愛学大歯誌 $18 ： 149-156,1980$.

11）樢養 弘：咬合高径の変化によって現れる口内法描記板上の各運動路の変化について. 補緅誌 5：52一 56 , 1961.

12）丸山雅昭：種々な下顎位における下䞄の急速反復開閉運動に関する研究. 補経誌 $17: 308-332 ， 1973$.

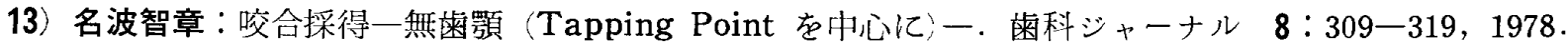

14）河江 信：下顎開閉運動の動態汇関する研究. 補緅誌 $24: 647-671,1980$.

15）雨宮幸三・川添堯彬・西浦 怕・藤井輝久・藤井忠弘：無崡顎の Gothic Arch Apex と Tapping Point の相互的観察. 歯科医学 $33: 289-299,1970$.

16）佐藤憲男：運動の巧みさからみた下顎位の機能的検索。補啜誌 $20 ： 734-754 ， 1976$.

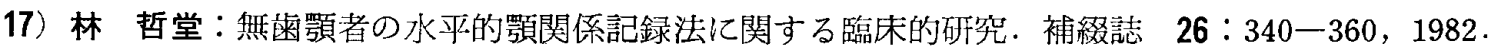

18）三谷春保・山下 敦・井上 去：Mandibular Kinesiograph の原理とその忠実性について。補緅誌 21 ： $254-265,1977$.

19）川口豊造・水野起良広・阪上隆則・小野 積・小川松弥・吉田 仁・鈴木立子：Mandibular Kinesiograph の歪について. 愛学大歯誌 $16: 1-12,1978$.

20) Jankelson, B. : Measurement accuracy of the mandibular kinesiograph - A computerized study.-J. Prosthet. Dent. $44: 656-666,1980$.

21）櫻井 毫：顎運動路描記装置の Stylus の設定位置が Tapping area に及ぼす影響に関する基礎的研究. 歯科学報 $81: 1495-1526,1981$.

22) Widmalm, S. and Hedegard, B.: Kinematics of the tooth tapping movement. J. Oral Rehabil. $4: 237-246,1977$.

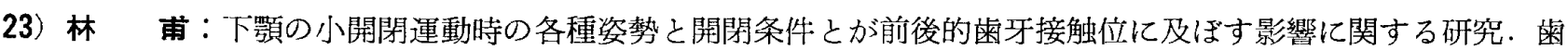
科学報 $80: 1-31,1980$.

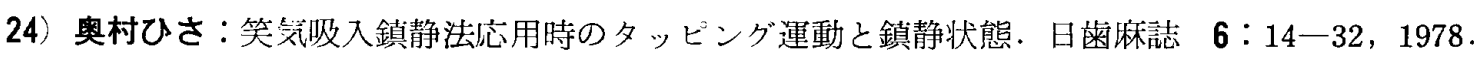

25）尾松素樹：顎位決定における tapping 時の力が tapping area の前後的位置に及ぼす影響に関する研究. 歯科学報 $83: 127-163,1983$.

26）佐久間孔毅：マルチフラッシュ装置による有雨顎者の前後および開閉運動の研究. 口病誌 $26: 1511-1536$, 1959.

27）川口豊造：電気的測定装置による習慣的閉口運動および燕下運動時の曾牙接触位に関する研究．補緅誌 $12: 397-422,1968$.

28) Sekine, H. and Kishi, M. : Experimental studies on the influences of sagittal inclination of body axis and head axis on the stability of the mandibular position. Bull. Tokyo Dent. Coll. $20: 135-143,1979$.

29）楊 欽榮：種々の体位ならびに咬合記録術式が咬合位に及ぼす影響. 九州歯会誌 $37 ： 265-282,1983$.

30）名波智章：咬合点に関する臨床実験的研究. 歯科学報 $72: 462-533,1972$.

31) Kurth, L.E. : Physics of mandibular movement related to full denture construction. $J$. Prosthet. Dent. $4: 611-620,1954$. 
32）阿部勝也：枵関節よりの求心性神経情報に関する研究. 歯基礎誌 16:117-128，1974.

33) Boos, R.H. : Occlusion from rest position. J. Prosthet. Dent. 2: 575-588, 1952.

34) Lammie, G.A., Perry, H.T. and Crumm, B.D. : Certain observation on a complete denture patients, Part II Electromyographic observations. J. Prosthet. Dent. 8:929-939, 1958.

35) Abe, K., Takata, M. and Kawamura, Y. : A study on the inhibition of masseteric $\alpha$-motor fiber discharges by mechanical stimulation of the temporomandibular joint in the cat. Arch. Oral Biol. $18: 301-304,1973$.

36）大石忠雄：下顎運動の立場汃引た顎関節構造の研究. 補経誌 $11: 197-220 ， 1967$.

37）川畑博昭：矢状面における各種顆頭位の研究，特に顆頭安定位について．補緅誌 15：403一429，1971.

38）鵜養 弘：中心咬合位の決定について. 米界展望 $21: 447-453 ， 1963$.

39）馬場暎一：ゴシックアーチ描記による咬合採得. 歯学 $61: 744-748,1973$.

40）坂田三弥：Overlay Denture をめぐって一生理学の立場から一. 歯科学報 79:615-623, 1979.

41）森田修己・旗手 敏：Over denture の連結機構による咬合と菌根膜の反射機序について. 日歯評論 $405: 45-59,1976$.

42）林都志夫：総義霜の咬合について. 日雨評論 $376: 97-110,1974$.

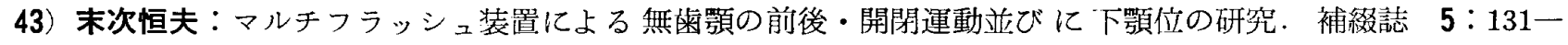
169,1961 . 